\title{
Cleanup Verification Package for the 100-F-20, Pacific Northwest Laboratory Parallel Pits
}

\author{
Prepared for the U.S. Department of Energy \\ by Washington Closure Hanford
}




\section{EXECUTIVE SUMMARY}

This cleanup verification package documents completion of remedial action for the 100-F-20, Pacific Northwest Laboratory (PNL) parallel pits waste site. The 100-F-20 site is located within the 100-FR-2 Operable Unit in the 100-F Area of the Hanford Site in southeastern Washington State. Prior to remediation, the waste site consisted of two earthen trenches located about $30.5 \mathrm{~m}$ (100 ft) west of the 100-F Perimeter Road. The trenches were thought to have received both radioactive and nonradioactive material related to the 100-F Experimental Animal Farm. The pre-remediation waste site dimensions measured approximately $22.9 \mathrm{~m}$ by $6.1 \mathrm{~m}$ by $2.4 \mathrm{~m}$ ( $75 \mathrm{ft}$ by $20 \mathrm{ft}$ by $8 \mathrm{ft}$ ) deep. After excavation, each burial pit was approximately $70 \mathrm{~m}(230 \mathrm{ft})$ in length and $4 \mathrm{~m}(13 \mathrm{ft})$ in depth.

Remedial action at the 100-F-20 site began on December 5, 2005, with load out of waste material completed on August 8, 2006. Remedial activities included removal of concrete, metal piping, steel sheeting, and wood - along with underlying contaminated soil. All contaminated materials removed from the 100-F-20 waste site were disposed of at the Environmental Restoration Disposal Facility. Results of the sampling, laboratory analyses, and data evaluations for the 100-F-20 site (which includes the remediation footprint and the above-cleanup-level staging pile footprint) indicate that all remedial action objectives and goals for direct exposure, protection of groundwater, and protection of the Columbia River have been met (see Table ES-1).

The site meets cleanup standards and has been reclassified as "interim closed out" in accordance with the Hanford Federal Facility Agreement and Consent Order (Ecology et al. 1989) and the Waste Site Reclassification Guideline TPA-MP-14 (RL-TPA-90-0001) (DOE-RL 1998). A copy of the waste site reclassification form is included as Attachment ES-1 to this document. 


\section{Table ES-1. Summary of Cleanup Verification Results for the 100-F-20 Burial Ground. (2 pages)}

\begin{tabular}{|c|c|c|c|c|}
\hline $\begin{array}{l}\text { Regulatory } \\
\text { Requirement }\end{array}$ & Remedial Action Goals & Results & $\begin{array}{l}\text { Remedial } \\
\text { Action } \\
\text { Objectives } \\
\text { Attained? }\end{array}$ & Ref. \\
\hline $\begin{array}{l}\text { Direct Exposure - } \\
\text { Radionuclides }\end{array}$ & $\begin{array}{l}\text { 1. Attain } 15 \mathrm{mrem} / \mathrm{yr} \text { dose rate } \\
\text { above background over } \\
1,000 \text { years. }\end{array}$ & $\begin{array}{l}\text { 1. All cumulative radionuclide } \\
\text { activities are below the } \\
\text { cumulative } 15 \mathrm{mrem} / \mathrm{yr} \text { dose rate. }\end{array}$ & Yes & d,e \\
\hline $\begin{array}{l}\text { Direct Exposure - } \\
\text { Nonradionuclides }\end{array}$ & 1. Attain individual COC RAGs. & $\begin{array}{l}\text { 1. Lead, the only nonradionuclide } \\
\text { COC, is below the direct } \\
\text { exposure criteria. }\end{array}$ & Yes & d,e \\
\hline \multirow{4}{*}{$\begin{array}{l}\text { Meet } \\
\text { Nonradionuclide } \\
\text { Risk } \\
\text { Requirements }\end{array}$} & $\begin{array}{l}\text { 1. Hazard quotient of }<1 \text { for } \\
\text { noncarcinogens. }\end{array}$ & $\begin{array}{l}\text { 1. Calculation of hazard quotient for } \\
\text { lead is not required. }\end{array}$ & NA & e \\
\hline & $\begin{array}{l}\text { 2. Cumulative hazard quotient of }<1 \\
\text { for noncarcinogens. }\end{array}$ & $\begin{array}{l}\text { 2. Cumulative hazard quotient } \\
\text { calculation not required. }\end{array}$ & NA & e \\
\hline & $\begin{array}{l}\text { Excess cancer risk of }<1 \times 10^{-6} \\
\text { for individual carcinogens. }\end{array}$ & $\begin{array}{l}\text { 3. There are no carcinogenic } \\
\text { nonradionuclide COCs for this } \\
\text { site. }\end{array}$ & NA & d,e \\
\hline & $\begin{array}{l}\text { 4. Attain a total excess cancer risk } \\
\text { of }<1 \times 10^{-5} \text { for carcinogens. }\end{array}$ & $\begin{array}{l}\text { 4. There are no carcinogenic } \\
\text { nonradionuclide COCs for this } \\
\text { site. }\end{array}$ & NA & d,e \\
\hline \multirow[t]{4}{*}{$\begin{array}{l}\text { Groundwater/ } \\
\text { River Protection - } \\
\text { Radionuclides }\end{array}$} & $\begin{array}{l}\text { 1. Attain single COC groundwater } \\
\text { and river protection RAGs. }\end{array}$ & $\begin{array}{l}\text { 1. Groundwater and river protection } \\
\text { RAGs for the radionuclide COCs } \\
\text { have been attained. }\end{array}$ & & d,e \\
\hline & $\begin{array}{l}\text { 2. Attain National Primary Drinking } \\
\text { Water Standards: } 4 \text { mrem/yr } \\
\text { (beta/gamma) dose rate to target } \\
\text { receptor/organs. }\end{array}$ & $\begin{array}{l}\text { 2. Based on RESRAD modeling } \\
\text { reported in } \mathrm{BHI} 2004^{\mathrm{g}} \text { and } \\
\mathrm{BHI} 2005^{\mathrm{h}} \text { residual concentrations } \\
\text { of the detected radionuclide } \\
\text { COCs in the } \mathrm{ACL} \text { staging pile } \\
\text { footprint are predicted to meet } \\
\text { the dose rate limit of } 4 \mathrm{mrem} / \mathrm{yr} \text {. }\end{array}$ & Yes & d \\
\hline & $\begin{array}{l}\text { 3. Meet drinking water standards for } \\
\text { alpha emitters: the more } \\
\text { stringent of the } 15 \mathrm{pCi} / \mathrm{L} \mathrm{MCL} \\
\text { or } 1 / 25 \text { th of the derived } \\
\text { concentration guide per } \\
\text { DOE Order } 5400.5 .^{\mathrm{b}}\end{array}$ & $\begin{array}{l}\text { 3. No alpha emitters were detected } \\
\text { in the verification samples. }\end{array}$ & Yes & d,e \\
\hline & $\begin{array}{l}\text { 4. Meet total uranium standard of } \\
21.2 \mathrm{pCi} / \mathrm{L} \text {. }\end{array}$ & $\begin{array}{l}\text { 4. Uranium is not a COC for this } \\
\text { site. }\end{array}$ & NA & \\
\hline $\begin{array}{l}\text { Groundwater/ } \\
\text { River Protection - } \\
\text { Nonradionuclides }\end{array}$ & $\begin{array}{l}\text { 1. Attain individual nonradionuclide } \\
\text { groundwater and river cleanup } \\
\text { requirements. }\end{array}$ & $\begin{array}{l}\text { 1. Lead exceeded groundwater and } \\
\text { river protection RAGs. However, } \\
\text { results of the } 100 \text { Area } \\
\text { Analogous Sites RESRAD } \\
\text { Calculations (BHI 2005) indicate } \\
\text { that this constituent will not reach } \\
\text { groundwater (and, therefore, the } \\
\text { Columbia River) within } \\
1,000 \text { years. Thus, the residual } \\
\text { concentrations achieve the RAOs } \\
\text { for groundwater and river } \\
\text { protection. }\end{array}$ & Yes & $d$ \\
\hline
\end{tabular}




\section{Table ES-1. Summary of Cleanup Verification Results for the 100-F-20 Burial Ground. (2 pages)}

\begin{tabular}{|l|c|c|c|c|}
\hline $\begin{array}{c}\text { Regulatory } \\
\text { Requirement }\end{array}$ & Remedial Action Goals & Results & $\begin{array}{c}\text { Remedial } \\
\text { Action } \\
\text { Objectives } \\
\text { Attained? }\end{array}$ & Ref. \\
\hline $\begin{array}{l}\text { Other supporting } \\
\text { Information }\end{array}$ & $\begin{array}{l}100-\mathrm{F}-20 \text { Cleanup Verification } 95 \% \text { UCL calculation (Appendix C). }{ }^{\mathrm{e}} \\
100-\mathrm{F}-20 \text { Shallow Zone and } \mathrm{ACL} \text { Stockpile Sampling Plan (Appendix C). }{ }^{\mathrm{f}}\end{array}$ & \\
\hline
\end{tabular}

a "National Primary Drinking Water Regulations" (40 Code of Federal Regulations 141).

b Radiation Protection of the Public and the Environment (DOE Order 5400.5).

c Based on the isotopic distribution of uranium in the Hanford Site background, the $30 \mu \mathrm{g} / \mathrm{L} \mathrm{MCL} \mathrm{(65} \mathrm{Federal} \mathrm{Register} \mathrm{76708)}$ corresponds to $21.2 \mathrm{pCi} / \mathrm{L}$. Concentration-to-activity calculations are documented in Calculation of Total Uranium Activity Corresponding to a Maximum Contaminant Level for Total Uranium of 30 Micrograms per Liter in Groundwater, 0100X-CA-V0038 (BHI 2001).

d The Cleanup Verification Package for the 100-F-20, Pacific Northwest National Lab Parallel Pits, CVP-2006-00009, Washington Closure Hanford, Richland, Washington.

e 100-F-20 Cleanup Verification 95\% UCL Calculations, 0100F-CA-V0274, Rev. 0, Washington Closure Hanford, Richland, Washington.

f 100-F-20 Shallow Zone and ACL Stockpile Sampling Plan, 0100F-CA-V0266, Rev. 0, Washington Closure Hanford, Richland, Washington.

$9 \mathrm{BHI}, 2004,100$ Area Radionuclide and Nonradionuclide Lookup Values for the 1995 Interim Remedial Action Record of Decision, 0100X-CA-V0046, Rev. 0, Bechtel Hanford, Inc., Richland, Washington

h BHI, 2005, 100 Area Analogous Sites RESRAD Calculations, 0100X-CA-V0050, Rev. 0, Bechtel Hanford, Inc., Richland, Washington.

$\mathrm{ACL}=$ above cleanup level

$\mathrm{NA}=$ not applicable

RESRAD = RESidual RADioactivity (dose model)

RAG = remedial action goal

RAO = remedial action objective

$\mathrm{COC}=$ contaminant of concern

$\mathrm{MCL}=$ maximum contaminant level 
CVP-2006-00009

Rev. 0

ES-4 
CVP-2006-00009

Rev. 0

\section{Attachment ES-1}

Waste Site Reclassification Form

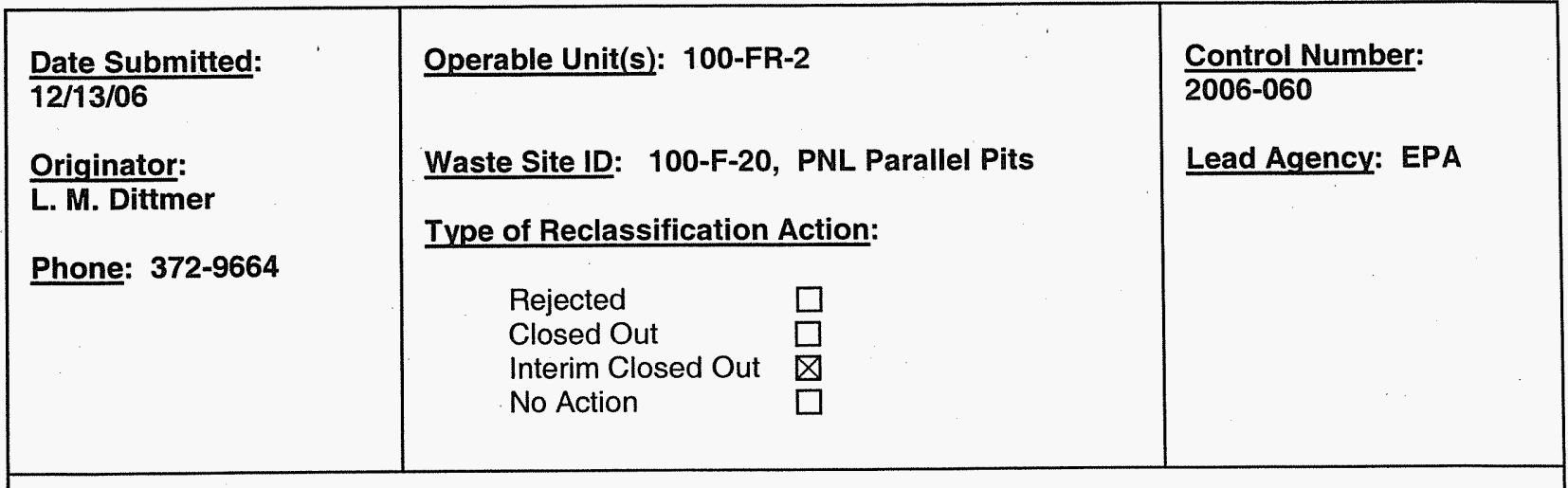

This form documents agreement among the parties listed below authorizing classification of the subject unit as rejected, closed out, or no action and authorizing backfill of the site, if appropriate. Final removal from the National Priorities List (NPL) of no action or closed-out sites will occur at a future date.

\section{Description of current waste site condition:}

Remedial action at this site has been performed in accordance with remedial action objectives and goals established by the U.S. Environmental Protection Agency and the Washington State Department of Ecology, in concurrence with the U.S. Department of Energy, Richland Operations Office. The 100-F-20 waste site includes the two remediated parallel pits, the strip of land between them, and the waste staging pile footprint. The selected remedial action involved (1) excavating the site to the extent required to meet specified soil cleanup levels, (2) disposing of contaminated excavation materials at the Environmental Restoration Disposal Facility at the 200 Area of the Hanford Site, and (3) backfilling the site with clean soil to adjacent grade elevations. These excavation and disposal activities have been completed.

\section{Basis for reclassification:}

The results of verification sampling of the soils at the 100-F-20 waste site demonstrated that residual contaminant concentrations do not preclude any future uses (as bounded by the rural-residential scenario) and allow for unrestricted use of shallow zone soils (i.e., surface to $4.6 \mathrm{~m}$ [15 ft] deep). The results also showed that residual contaminant concentrations are protective of groundwater and the Columbia River. The waste site does not have a deep zone; therefore, no institutional controls are required. The basis for reclassification is described in detail in the Cleanup Verification Package for the 100-F-20, Pacific Northwest Laboratory Parallel Pits (CVP-2006-00009), Washington Closure Hanford, Richland, Washington.

D. C. Smith

DOE Project Manager

NA

Ecology Project Manager

R. A. Lobos

EPA Project Manager
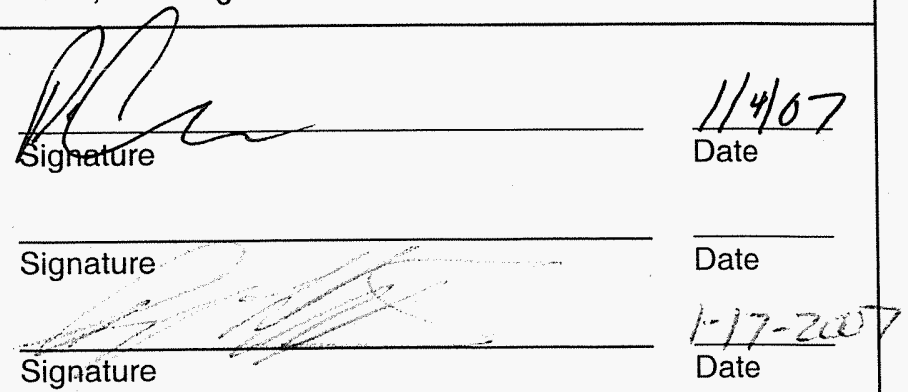
CVP-2006-00009

Rev. 0

ES-6 


\section{CONTENTS}

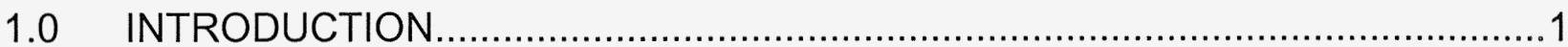

2.0 SITE DESCRIPTION AND SUPPORTING INFORMATION ...............................

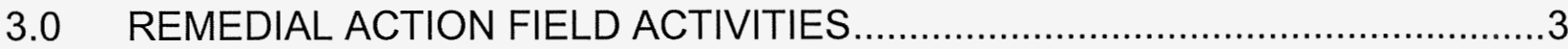

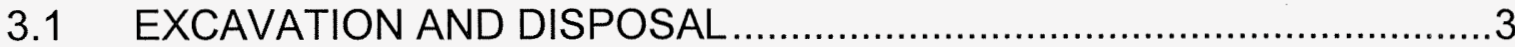

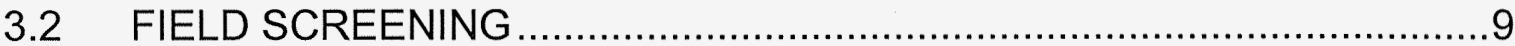

3.3 CLEANUP VERIFICATION SAMPLING AND ANALYSIS ......................

4.0 CLEANUP VERIFICATION DATA EVALUATION .......................................13

4.1 DATA QUALITY ASSESSMENT PROCESS ....................................13

4.2 CONTAMINANTS OF CONCERN 95\% UPPER CONFIDENCE LIMIT ...13

4.3 RESRAD MODELING …............................................................. 14

5.0 EVALUATION OF REMEDIAL ACTION GOAL ATTAINMENT ….....................15

5.1 DIRECT EXPOSURE SOIL REMEDIAL ACTION GOALS ATTAINED ....15

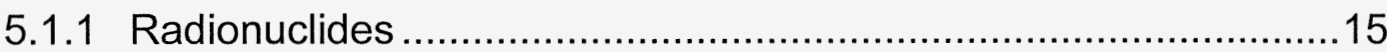

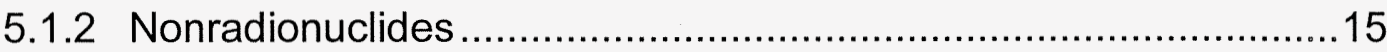

5.2 GROUNDWATER REMEDIAL ACTION GOALS ATTAINED ..................16

5.2.1 Radionuclides .....................................................................16

5.2.2 Nonradionuclides ............................................................. 17

5.3 COLUMBIA RIVER REMEDIAL ACTION GOALS ATTAINED ................18

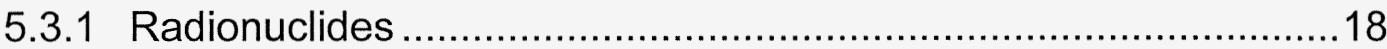

5.3.2 Nonradionuclides ................................................................ 18

5.4 WAC 173-340 THREE-PART TEST FOR NONRADIONUCLIDES ..........18

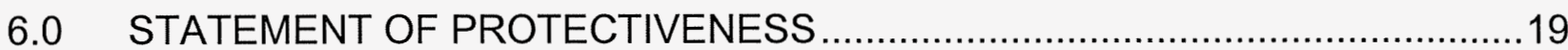

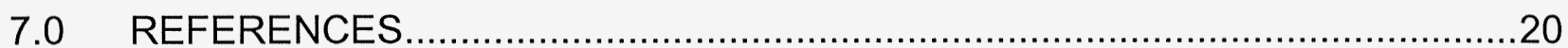

\section{APPENDICES}

A SUMMARY OF VERIFICATION SOIL SAMPLING RESULTS FOR THE 100-F-20 WASTE SITE COCs ........................................................................ A

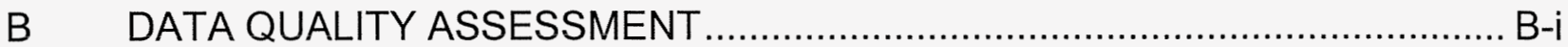

C CALCULATION BRIEF EXCERPTS .......................................................... C-i

C1 100-F-20 Shallow Zone and ACL Stockpile Sampling Plan, 0100F-CA-V0266

C2 100-F-20 Cleanup Verification 95\% UCL Calculations, 0100F-CA-V0274 


\section{FIGURES}

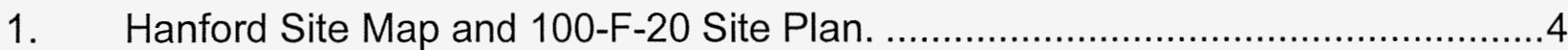

2. Photograph of the 100-F-20 Parallel Pits (1962 aerial photograph,

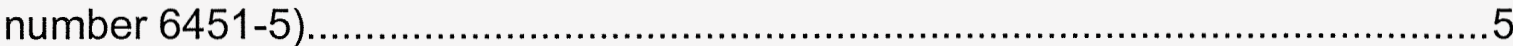

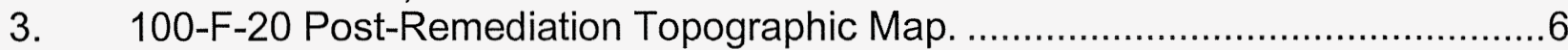

4. Photograph of 100-F-20 Burial Ground Remediation Debris.............................

5. Photograph of 100-F-20 Remediation Activities............................................. 8

6. GPERS Radiological Survey Gamma Track Map of the 100-F-20 Remediation Footprint (January 31, 2006).

7. GPERS Radiological Survey Gamma Track Map of the Interstitial Land Between the 100-F-20 Parallel Pits (January 15, 2007)

8. GPERS Radiological Survey Gamma Track Map of the Waste Staging Pile Footprint (January 15, 2007).

\section{TABLES}

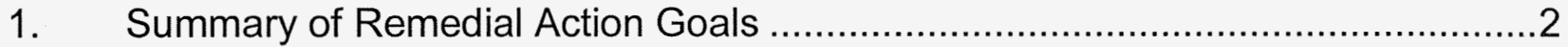

2. Cleanup Verification Data Set. ................................................................... 14

3. Attainment of Radionuclide Direct Exposure RAG for the ACL Staging Pile

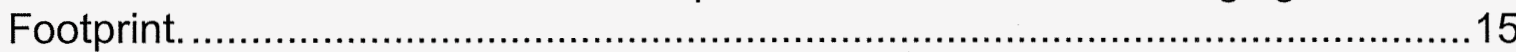

4. Attainment of Nonradionuclide Direct Exposure Standards. ............................16

5. Attainment of Nonradionuclide Remedial Action Goals for Protection of Groundwater and the Columbia River.

6. Application of the WAC 173-340 Three-Part Test 


\section{ACRONYMS AND ABBREVIATIONS}

$\begin{array}{ll}\text { ACL } & \text { above cleanup level } \\ \text { COC } & \text { contaminant of concern } \\ \text { DQA } & \text { data quality assessment } \\ \text { EPA } & \text { U.S. Environmental Protection Agency } \\ \text { ERDF } & \text { Environmental Restoration Disposal Facility } \\ \text { GPERS } & \text { Global Positioning Environmental Radiological Surveyor } \\ \text { ICP } & \text { inductively coupled plasma } \\ \text { MCL } & \text { maximum contaminant level } \\ \text { RAG } & \text { remedial action goal } \\ \text { RDR/RAWP } & \text { remedial design report/remedial action work plan } \\ \text { RESRAD } & \text { RESidual RADioactivity (dose assessment model) } \\ \text { ROD } & \text { record of decision } \\ \text { SAP } & \text { sampling and analysis plan } \\ \text { UCL } & \text { upper confidence limit } \\ \text { WAC } & \text { Washington Administrative Code }\end{array}$


CVP-2006-00009

Rev. 0 


\subsection{INTRODUCTION}

The purpose of this cleanup verification package is to document that the $100-\mathrm{F}-20$ waste site was remediated in accordance with the Record of Decision for the 100-BC-1, 100-BC-2, 100-DR-1, 100-DR-2, 100-FR-2, 100-HR-2, and 100-KR-2 Operable Units, Hanford Site (100 Area Burial Grounds), (ROD), Benton County, Washington (EPA 2000). Remedial action objectives and goals for the 100-F-20 site were established by the U.S. Environmental Protection Agency (EPA) and the U.S. Department of Energy, Richland Operations Office, in concurrence with the Washington State Department of Ecology. These goals and objectives are documented in the 100 Area Burial Grounds ROD (EPA 2000) and the Remedial Design Report/Remedial Action Work Plan for the 100 Area (RDR/RAWP) (DOE-RL 2005). The ROD (EPA 2000) provides the U.S. Department of Energy, Richland Operations Office the authority, guidance, and objectives to conduct this remedial action.

The preferred remedy specified in the ROD (EPA 2000) and conducted for the 100-F-20 site included: (1) excavating the site to the extent required to meet specified soil cleanup levels, (2) disposing of contaminated excavation materials at the Environmental Restoration Disposal Facility (ERDF) at the 200 Area of the Hanford Site, and (3) backfilling the site with clean soil to the average adjacent grade elevation. Excavation was driven by remedial action objectives for direct exposure, protection of groundwater, and protection of the Columbia River. For the respective points of compliance, the remedial action goals (RAGs), summarized in Table 1, were established for the radionuclide and nonradionuclide contaminants of concern (COCs). Waste site COCs were identified in the 100 Area Burial Grounds Remedial Action Sampling and Analysis Plan (SAP) (DOE-RL 2001) and included cobalt-60, strontium-90, and plutonium-239/240. Cesium-137 and lead were detected above background in the in-process soil samples and were, therefore, added as waste site COCs. Additionally, nickel- 63 was added as a COC because of a single detection in the cleanup verification samples for the above-cleanup-level $(A C L)$ staging pile footprint.

Soil cleanup levels were established in the interim action ROD based on a limited ecological risk assessment. Although not required by the ROD (EPA 2000), a screening comparison against ecological risk screening levels has been made for the site COCs, as identified in the RDR/RAWP. Lead exceeded the screening level values. However, exceedance of screening values does not necessarily indicate the existence of risk to ecological receptors. It is believed that the presence of lead does not pose a risk to ecological receptors as the concentrations are within the range of Hanford Site background levels. The exceedance of soil values by lead at the site will be evaluated in the context of additional lines of evidence for ecological effects. A baseline risk assessment for the river corridor portion of the Hanford Site began in 2004, which includes a more complete quantitative ecological risk assessment. That baseline risk assessment will be used as part of the final closeout decision for this site. 
Table 1. Summary of Remedial Action Goals. ${ }^{a}$

\begin{tabular}{|c|c|c|c|}
\hline cocs & $\begin{array}{c}\text { Direct Exposure } \\
\text { RAG }\end{array}$ & $\begin{array}{l}\text { Groundwater } \\
\text { Protection RAG } \\
\text { (pCi/L) }\end{array}$ & $\begin{array}{l}\text { Columbia River } \\
\text { Protection RAG } \\
\qquad(\mathrm{pCi} / \mathrm{L})\end{array}$ \\
\hline \multicolumn{4}{|c|}{ Radionuclides } \\
\hline Cobalt-60 & \multirow{5}{*}{$\begin{array}{l}15 \mathrm{mrem} / \mathrm{yr} \\
\text { (cumulative) }^{\mathrm{b}}\end{array}$} & \multirow{3}{*}{$\begin{array}{c}4 \mathrm{mrem} / \mathrm{yr} \\
\text { (cumulative) }^{\mathrm{c}}\end{array}$} & \multirow{3}{*}{$\begin{array}{c}4 \mathrm{mrem} / \mathrm{yr} \\
\text { (cumulative) }^{\mathrm{c}}\end{array}$} \\
\hline Cesium-137 & & & \\
\hline Nickel-63 & & & \\
\hline Plutonium-239/240 & & $15 / 1.2^{d}$ & $15 / 1.2^{d}$ \\
\hline Strontium-90 & & $8^{e, f}$ & $8^{\mathrm{e}, \mathrm{f}}$ \\
\hline cocs & $\begin{array}{c}\text { Direct Exposure } \\
\text { RAGs } \\
(\mathrm{mg} / \mathrm{kg})\end{array}$ & $\begin{array}{c}\text { Soil RAG for } \\
\text { Groundwater Protection } \\
(\mathrm{mg} / \mathrm{kg})\end{array}$ & $\begin{array}{l}\text { Soil RAG for Columbia } \\
\text { River Protection } \\
\text { (mg/kg) }\end{array}$ \\
\hline \multicolumn{4}{|c|}{ Nonradionuclides } \\
\hline Lead & $353^{g}$ & $10.2^{h}$ & $10.2^{h}$ \\
\hline
\end{tabular}

a Lookup values and RAGs obtained from the Remedial Design Report/Remedial Action Work Plan for the 100 Area (RDR/RAWP) (DOE-RL 2005) or calculated per WAC-173-340-720, 173-340-730, and 173-340-740, Method B, 1996, unless otherwise noted.

b Lookup values that correspond to the $15 \mathrm{mrem} / \mathrm{yr}$ dose rate are based on a generic site model and are presented in the 100 Area RDR/RAWP (DOE-RL 2005).

c Lookup values based on individual radionuclide $4 \mathrm{mrem} / \mathrm{yr}$ dose rate equivalent for beta and gamma emitters per National Drinking Water Standards as presented in the 100 Area Burial Grounds Remedial Action Sampling and Analysis Plan (DOE-RL 2001). Alpha emitters must meet drinking water standards based on the more conservative of the $15 \mathrm{pCi} / \mathrm{L}$ maximum contaminant level or 1/25th of the derived concentration guide per DOE Order 5400.5 .

d The two values are, respectively, the alpha emitter maximum contaminant level (MCL) from $40 \mathrm{Code}$ of Federal Regulations (CFR) 141 (15 pCi/L) and the drinking water standard from DOE Order 5400.5 (1/25th of the derived concentration guidelines). The more conservative of the two values is used.

e Strontium-90 contributes to the $4 \mathrm{mrem} / \mathrm{yr}$ (cumulative) RAG for groundwater and river protection.

f Promulgated groundwater protection standard (40 CFR 141).

9 RAG derived from Guidance Manual for the Integrated Exposure Uptake Biokinetic Model for Lead in Children (EPA 1994).

h Where cleanup levels are less than background, cleanup levels default to background (WAC 173-340-700[4][d]) (1996).

COC = contaminant of concern

CFR = Code of Federal Regulations

DOE = Department of Energy

EPA = Environmental Protection Agency

MCL = maximum contaminant level

RAG = remedial action goal

RDR/RAWP = remedial design report/remedial action work plan

WAC $=$ Washington Administrative Code 


\subsection{SITE DESCRIPTION AND SUPPORTING INFORMATION}

The 100-F-20 site is located in the 100-FR-2 Operable Unit of the 100-F Area at the Hanford Site. The site is located approximately $30.5 \mathrm{~m}(100 \mathrm{ft})$ west of the $100-\mathrm{F}$ Perimeter Road and immediately north of a dirt road that connects the 100-F Perimeter Road with the main reactor site (Figure 1) and measures approximately $22.9 \mathrm{~m}$ by $6.1 \mathrm{~m}$ by $2.4 \mathrm{~m}(75 \mathrm{ft}$ by $20 \mathrm{ft}$ by $8 \mathrm{ft}$ ) deep. The burial ground, which consisted of two earthen pits or trenches, started operation in 1962 and is thought to have been related to the $100-F$ Experimental Animal Farm. Both radioactive and nonradioactive waste was disposed of in the burial ground. The two parallel pits were identified by ground penetrating radar (GPR) and electromagnetic induction (EMI) data (BHI 1995, DOE-RL 2001). According to GPR and EMI data, the northwestern trench contained highly-

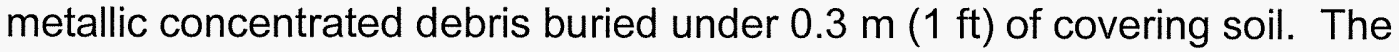
southeastern trench was believed to have contained radioactive animal feces and pen sweepings. A radiological survey conducted over the area of the parallel pits in 1995 showed ground surface readings as high as 12,000 counts per minute (DOE-RL 2001).

\subsection{REMEDIAL ACTION FIELD ACTIVITIES}

\subsection{EXCAVATION AND DISPOSAL}

Remedial action at the 100-F-20 site began on December 5, 2005, with load out of waste material completed on August 8, 2006. Excavation of the site involved removing demolition debris that contained concrete, metal piping, steel sheeting, and wood (WCH 2006). Approximately 14 small laboratory-type containers were encountered throughout the burial ground. No asbestos-containing material was identified during waste excavation and no areas of the burial ground were identified for focused sampling (WCH 2006). After removal of all debris, radiological field screening was used to determine that excavation activities were complete (Section 3.2). At the conclusion of the excavation activities, the remediation footprint was approximately $4.3 \mathrm{~m}(14 \mathrm{ft})$ below the ground surface and at the deepest point the elevation at the bottom of the excavation was $117 \mathrm{~m}$ (384 ft) above sea level. An estimated 11,953 metric tons $(13,176$ U.S. tons) of material was excavated from the $100-F-20$ burial ground and disposed at ERDF. All contaminated materials removed from the $100-\mathrm{F}-20$ waste site were disposed of at ERDF. 
Figure 1. Hanford Site Map and 100-F-20 Site Plan.

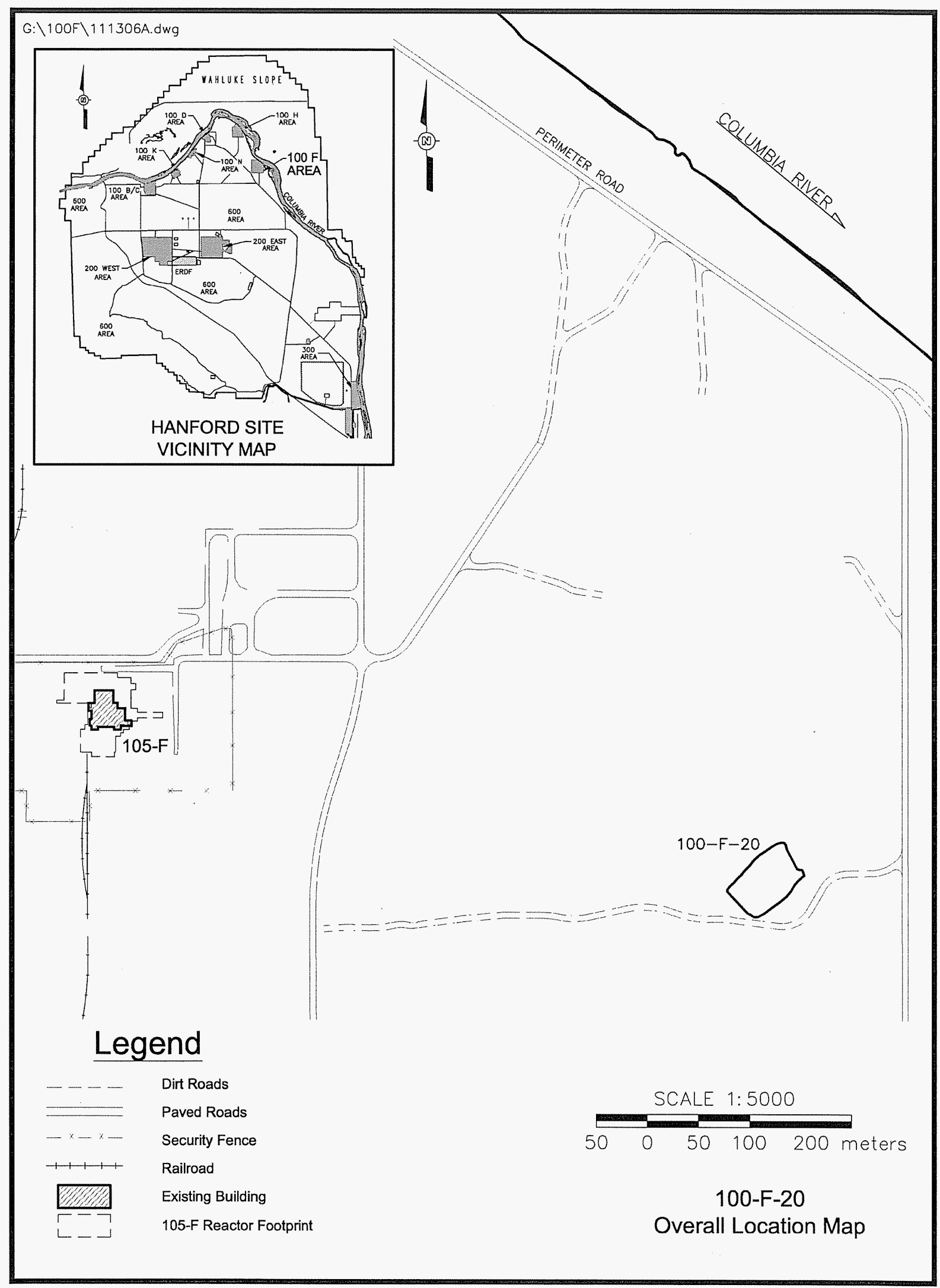


A photograph of the waste site in 1962 is provided in Figure 2. The two parallel pits identified by GPR in 1995 (BHI 1995), are clearly visible in the lower left corner of the photograph. The post-remediation topographic map is provided in Figure 3 . The $100-F-20$ waste site includes the two parallel pit footprints, the strip of land between them, and the above-cleanup-level (ACL) waste staging pile footprint. There is no overburden pile for the 100-F-20 waste site. The burial ground debris was shallow

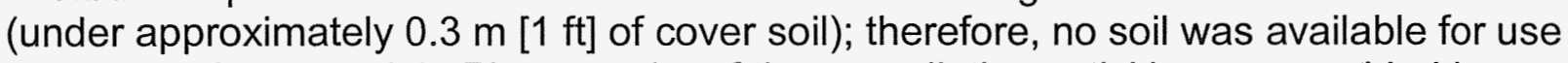
as overburden material. Photographs of the remediation activities are provided in Figures 4 and 5.

\section{Figure 2. Photograph of the 100-F-20 Parallel Pits (1962 aerial photograph, number 6451-5).}

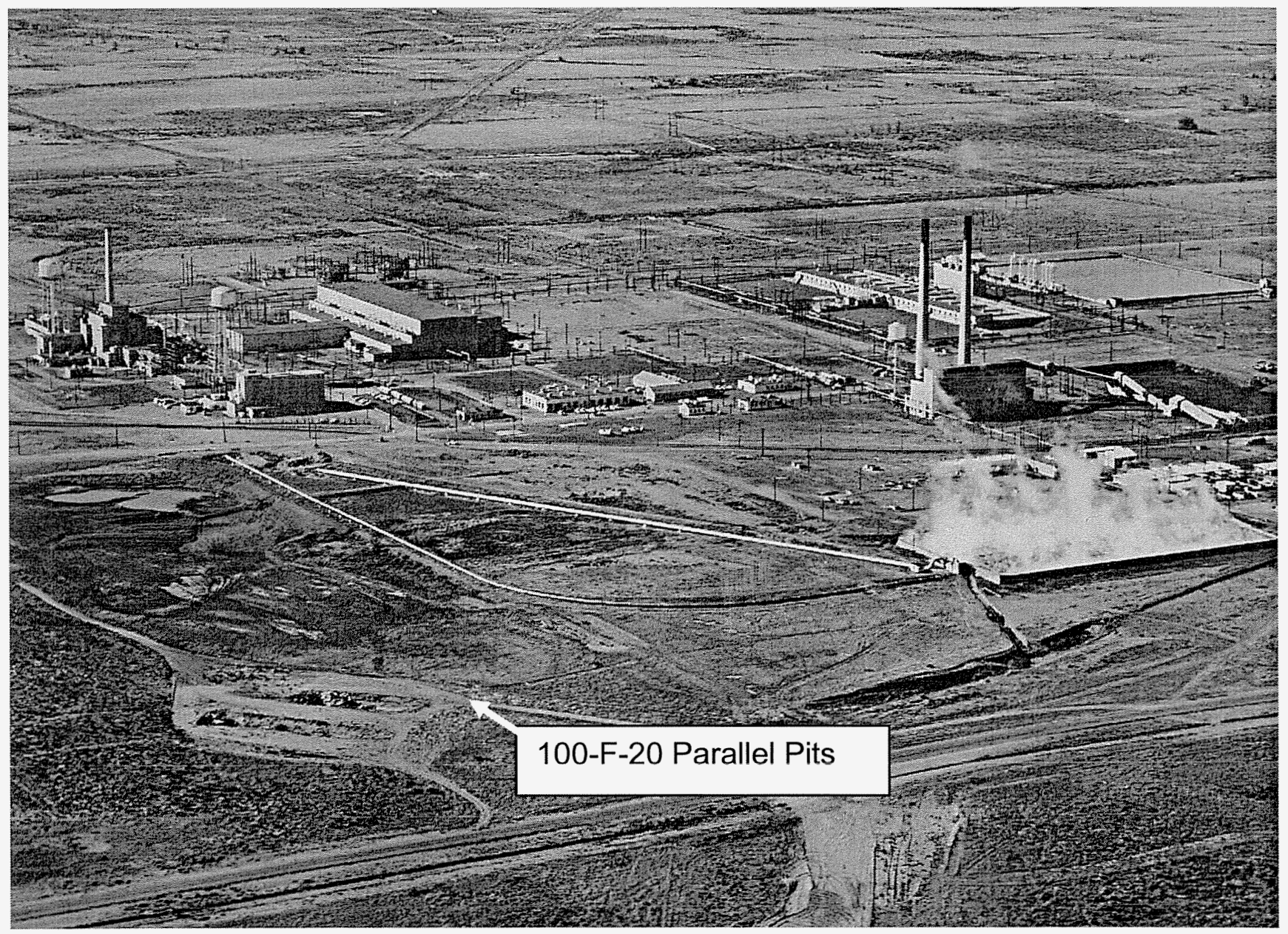


Figure 3. 100-F-20 Post-Remediation Topographic Map.

$G: \backslash 100 F \backslash 111306 C . d w g$

1

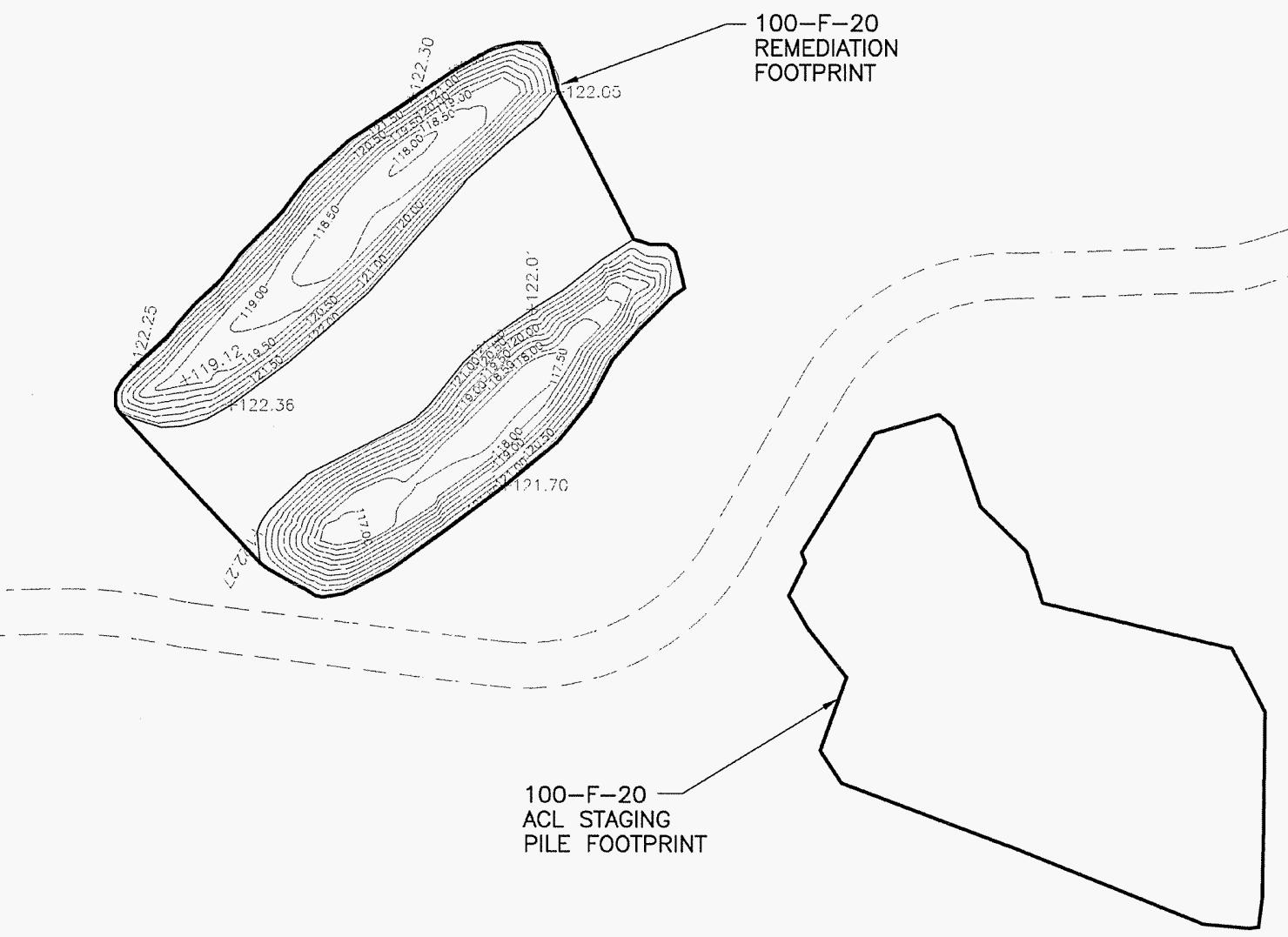

Legend

$= \pm= \pm \quad$ Dirt Road

SCALE 1:1000

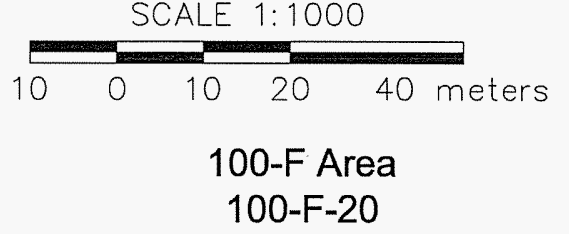

Note: 1. Vertical Datum: National Geodetic Survey Datum (NAVD88)

Post-Excavation Topography Map 
CVP-2006-00009

Rev. 0

Figure 4. Photograph of 100-F-20 Burial Ground Remediation Debris.

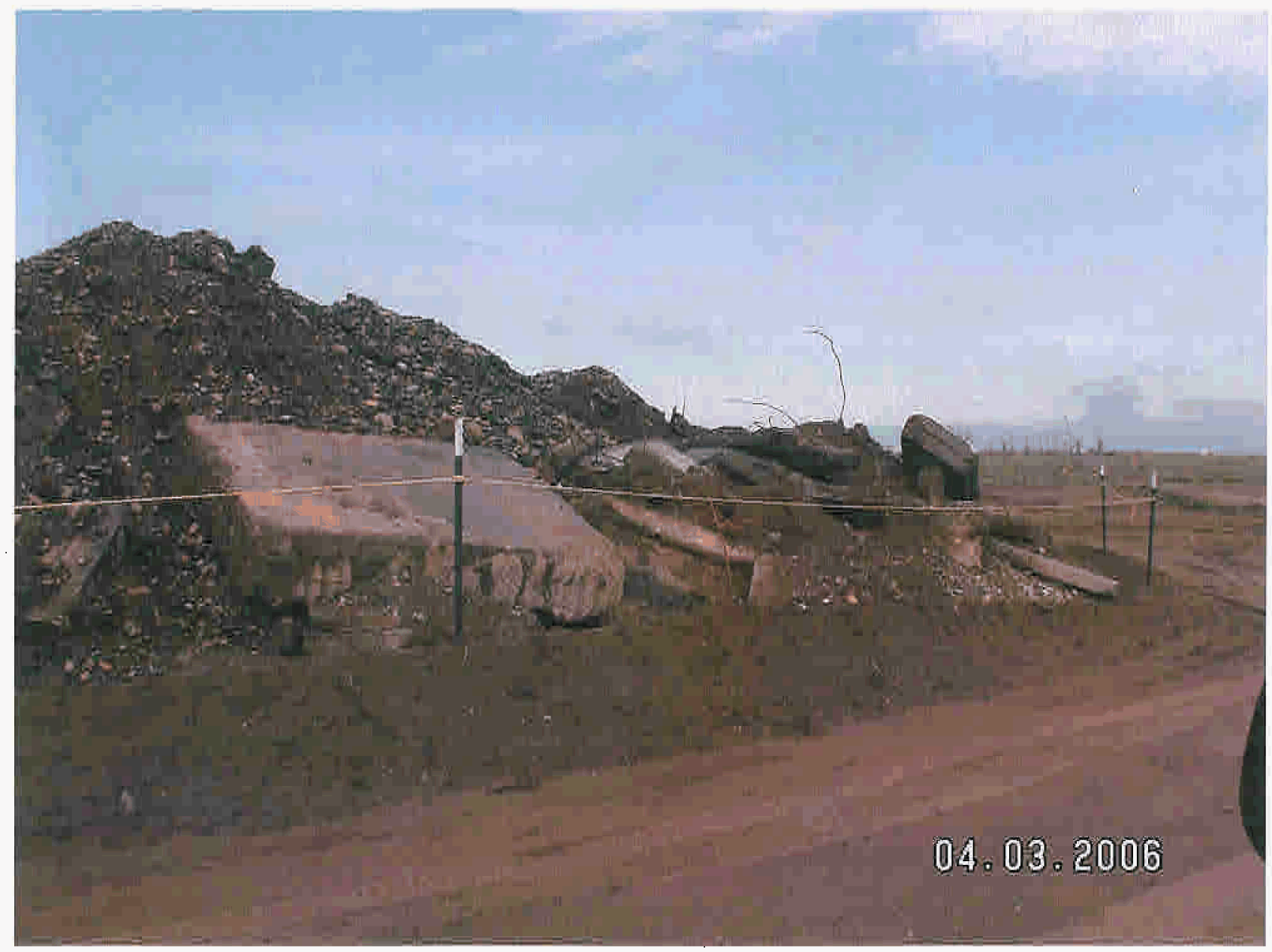


Figure 5. Photograph of 100-F-20 Remediation Activities.

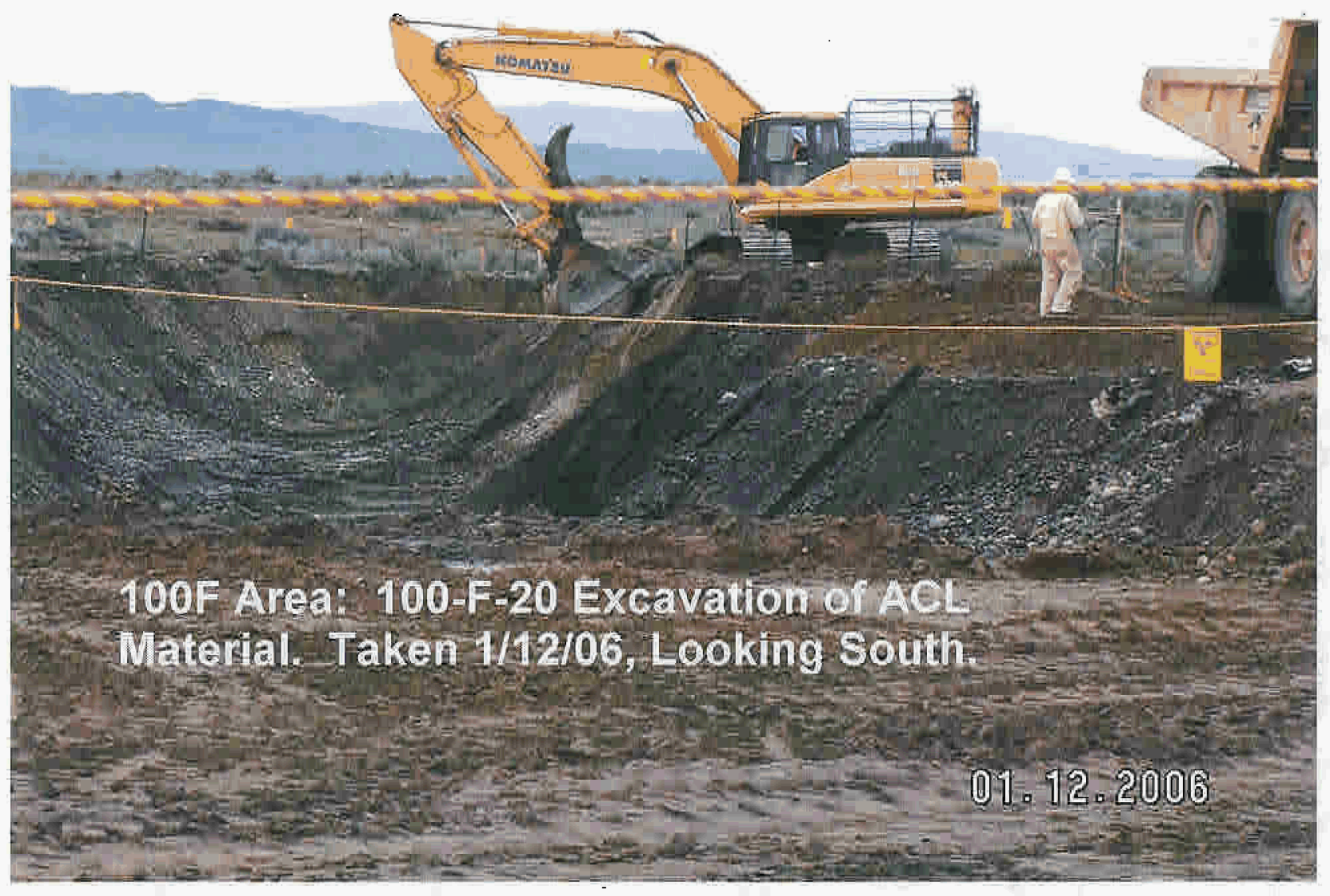




\subsection{FIELD SCREENING}

In-process characterization samples were analyzed for the COCs identified in the 100 Area Burial Grounds Remedial Action Sampling and Analysis Plan (DOE-RL 2001) along with a wide range of metals, semi-volatile organic compounds, gamma energy emitting isotopes, gross alpha, and gross beta. Cesium-137 and lead were detected above background in the in-process characterization samples and were, therefore, added as waste site COCs for the cleanup verification samples.

Radiological field screening was conducted during the site remedial actions as specified in the SAP (DOE-RL 2001). Field screening was used to guide the excavation to quickly assess the presence and level of contamination. Field screening at the site included using a radiological data mapping system survey. The radiological mapping survey was performed over more than $50 \%$ of the site excavation surface area using a Global Positioning Environmental Radiological Surveyor (GPERS). No significant levels of radiological activity were detected during the radiological field screening, as shown in Figure 6 , and, therefore, no further remediation was required prior to collection of the final cleanup verification samples.

Additional radiological field screening was performed in January of 2007 for the waste staging pile footprint and the interstitial land between the two parallel pits in order to support waste site close-out. The GPERS surveys are provided in Figures 7 and 8 . No significant levels of radiological activity were detected and, therefore, no further remediation was required.

\subsection{CLEANUP VERIFICATION SAMPLING AND ANALYSIS}

Final cleanup verification samples were collected in August of 2006 to confirm acceptability of residual contaminant concentrations in the soil at the 100-F-20 waste site. The verification samples were submitted to offsite laboratories for analysis using approved EPA analytical methods, as required per the 100 Area Burial Grounds Remedial Action Sampling and Analysis Plan (DOE-RL 2001). The 100-F-20 site was excavated to a depth of approximately $4.3 \mathrm{~m}(14 \mathrm{ft})$ below ground surface. The $100-F-20$ remediation excavation footprint was classified as one shallow-zone decision unit based on its size and depth. The above-cleanup-level (ACL) staging pile footprint is a separate decision unit. As specified in the SAP (DOE-RL 2001), four composite samples and a duplicate were collected from each of the waste site decision units. The duplicate samples were analyzed for the expanded list of inductively coupled plasma (ICP) metals, in addition to the listed COCs. 


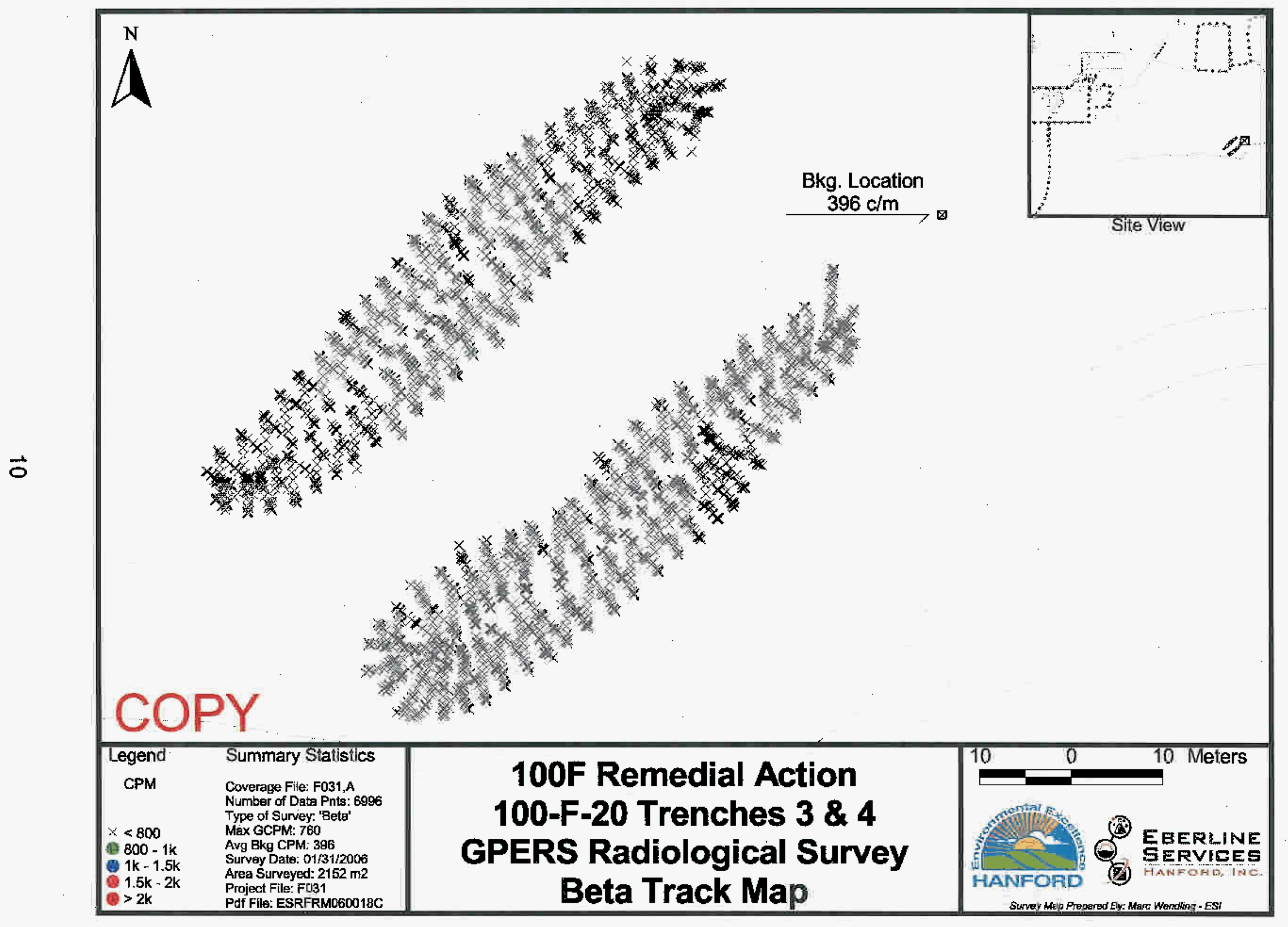

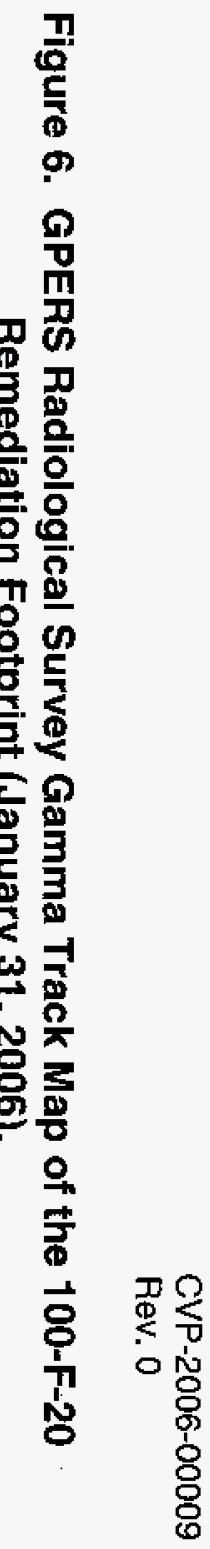




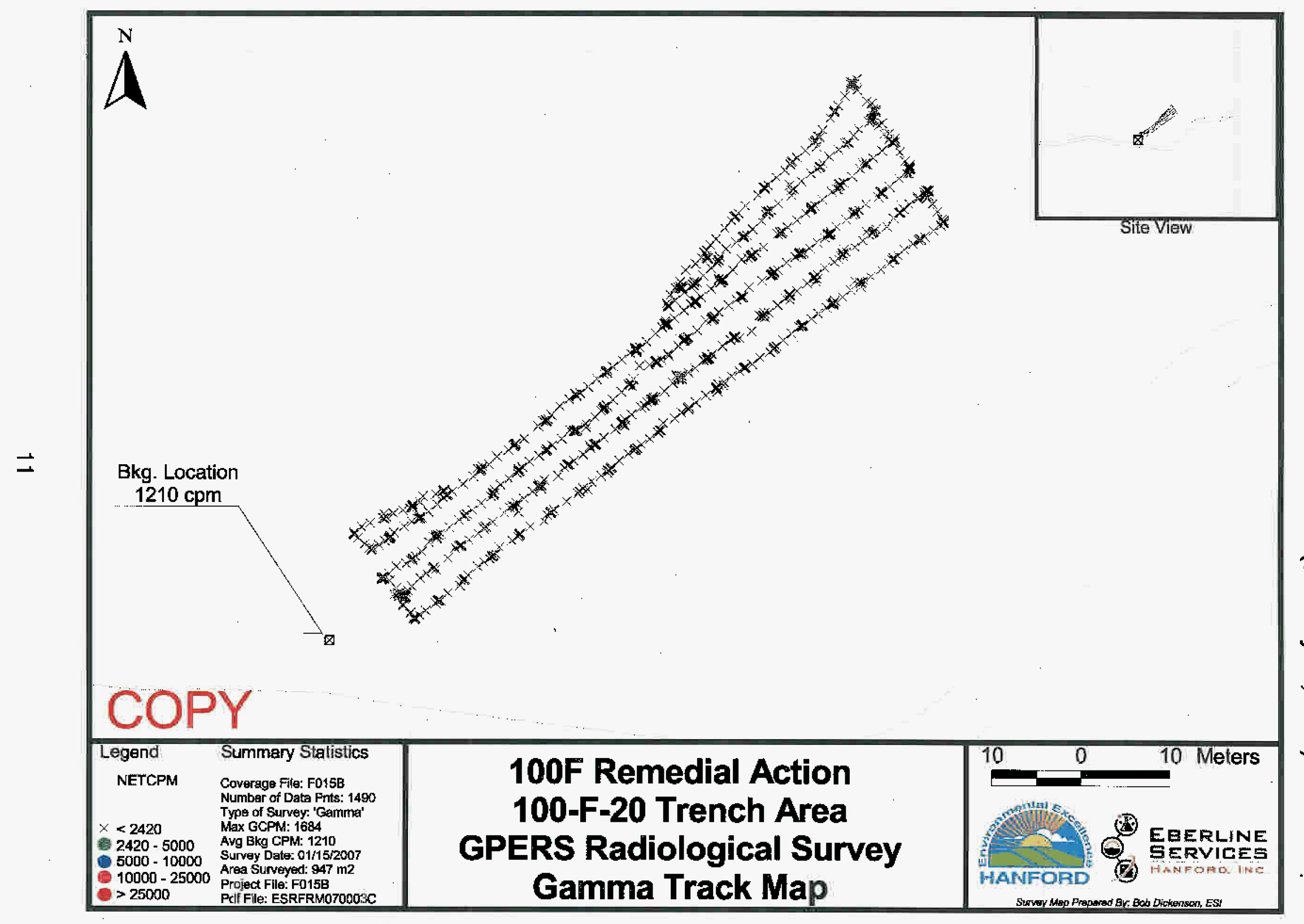

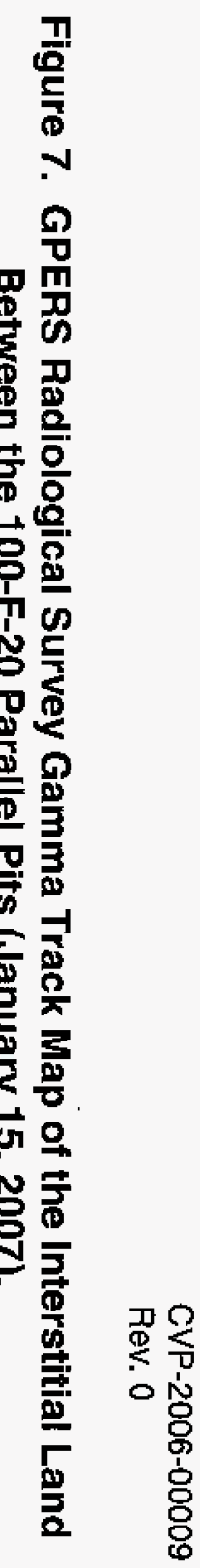




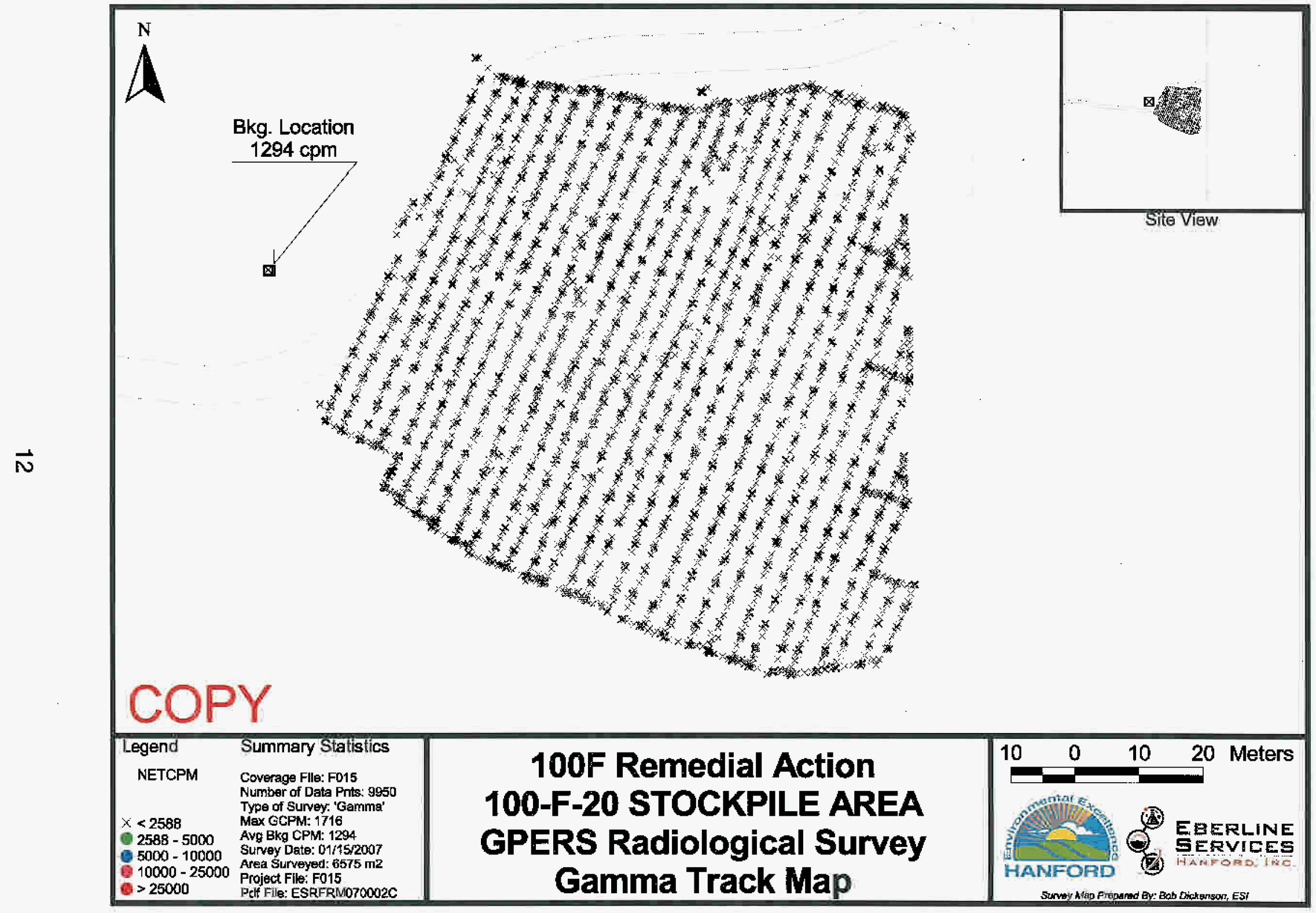

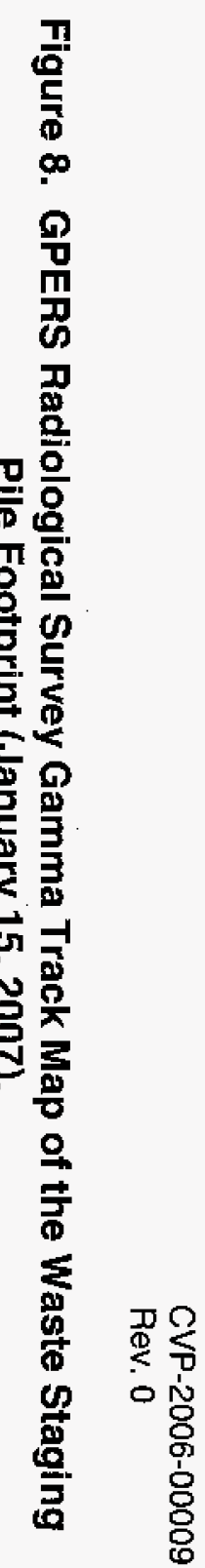


Verification sampling was performed by dividing each decision unit (i.e., the excavation footprint and $A C L$ staging pile footprint) into four sampling areas (A1, $A 2, A 3$, and $A 4$ ) with the sampling areas further divided into 16-node sample grids. One statistical verification sample was collected per sampling area by compositing soil collected at four randomly selected nodes. As such, each decision unit was represented by four composite statistical verification samples. The sample design methodology and sample location figures are presented in the verification sample design calculation brief in Appendix C.

\subsection{CLEANUP VERIFICATION DATA EVALUATION}

This section presents the evaluation of the 100-F-20 cleanup verification data for comparison with the data quality criteria and RAGs.

\subsection{DATA QUALITY ASSESSMENT PROCESS}

A data quality assessment (DQA) was performed to compare the verification sampling approach and resulting analytical data with the sampling and data quality requirements specified by the project objectives and performance specifications.

The DQA for the 100-F-20 site determined that the data are of the correct type, quality, and quantity to support site verification decisions within specified error tolerances. All analytical data were found acceptable for decision-making purposes. The evaluation verified that the sample design was sufficient for the purpose of clean site verification. The cleanup verification sample analytical data are stored in the Environmental Restoration project-specific database for data evaluation prior to being submitted for inclusion in the Hanford Environmental Information System database. The verification data are summarized in Appendix A. The detailed DQA is presented in Appendix B.

\subsection{CONTAMINANTS OF CONCERN 95\% UPPER CONFIDENCE LIMIT}

The primary statistical calculation to support cleanup verification is the $95 \%$ upper confidence limit (UCL) on the arithmetic mean of the data. The $95 \% \mathrm{UCL}$ values for each COC are computed for each decision unit (e.g., for the shallow zone and ACL staging pile footprint). Prior to calculating the $95 \% \cup C L$, the individual sample results are reviewed and, as appropriate, adjusted per the SAP (DOE-RL 2001) and RDR/RAWP (DOE-RL 2005). This process is summarized below.

For radionuclides, the laboratory-reported value is used in the calculation of the $95 \%$ UCL. In cases where the laboratory does not report a value for data qualified with a "U" (i.e., less than the detection limit), one-half of the minimum detectable activity is used in the calculation of the $95 \%$ UCL. For nonradionuclides, a value equal to one-half the practical quantitation limit is used for data flagged with a " $U$ " (i.e., less than the detection 
limit) in the calculation of the $95 \% \mathrm{UCL}$, as required by Washington Administrative Code (WAC) 173-340-740[7][g]. If greater than half of the sample results for a given nonradionuclide $\mathrm{COC}$ are below detection, the statistical value is set equal to the maximum concentration detected (i.e., versus computing a $95 \% \mathrm{UCL}$ ).

Verification sampling summary statistics (95\% UCL values) are listed in Table 2. Individual sample cleanup verification results are presented in Appendix A. The columns on the left side of Table 2 are the COCs and the 95\% UCL values before subtraction of background. The fourth column of Table 2 presents the background, where values exist, and the last three columns present the statistical values, which becomes the cleanup verification data set used for further evaluation and modeling.

Table 2. Cleanup Verification Data Set.

\begin{tabular}{|c|c|c|c|c|c|}
\hline \multirow{2}{*}{ cocs } & \multicolumn{2}{|c|}{$\begin{array}{l}95 \% \text { UCL Statistical Values }{ }^{\mathrm{a}} \\
(\mathrm{pCi} / \mathrm{g})\end{array}$} & \multirow{2}{*}{$\begin{array}{l}\text { Hanford Site } \\
\text { Background } \\
\text { (pCi/g) }\end{array}$} & \multicolumn{2}{|c|}{$\begin{array}{l}\text { Cleanup Verification Data Set } \\
\qquad(\mathrm{pCi} / \mathrm{g})\end{array}$} \\
\hline & Shallow Zone & $\begin{array}{l}\text { ACL Staging } \\
\text { Pile Footprint }\end{array}$ & & Shallow Zone & $\begin{array}{l}\text { ACL Staging Pile } \\
\text { Footprint }\end{array}$ \\
\hline Cobalt-60 & 0.053 (ND) & $0.140(\mathrm{ND})$ & 0.008 & 0.053 (ND) & $0.140(\mathrm{ND})$ \\
\hline Cesium-137 & 0.024 (ND) & 0.052 & 1.1 & 0.024 (ND) & 0.052 \\
\hline Nickel-63 & -0.192 (ND) & 1.91 & NA & $-0.192(\mathrm{ND})$ & 1.91 \\
\hline Plutonium-239/240 & 0.025 (ND) & 0.057 (ND) & 0.025 & 0.025 (ND) & 0.057 (ND) \\
\hline Strontium-90 & 0.075 (ND) & 0.141 & 0.18 & 0.075 (ND) & 0.141 \\
\hline \multirow{2}{*}{ cocs } & \multicolumn{2}{|c|}{$\begin{array}{l}\text { 95\% UCL Statistical Values }{ }^{a} \\
(\mathrm{mg} / \mathrm{kg})\end{array}$} & \multirow{2}{*}{$\begin{array}{c}\text { Hanford Site } \\
\text { Background } \\
(\mathrm{mg} / \mathrm{kg})\end{array}$} & \multicolumn{2}{|c|}{$\begin{array}{l}\text { Cleanup Verification Data Set } \\
(\mathrm{mg} / \mathrm{kg})\end{array}$} \\
\hline & Shallow Zone & $\begin{array}{l}\text { ACL Staging } \\
\text { Pile Footprint }\end{array}$ & & Shallow Zone & $\begin{array}{l}\text { ACL Staging Pile } \\
\text { Footprint }\end{array}$ \\
\hline Lead & 24.1 & 18.0 & 10.2 & 24.1 & 18.0 \\
\hline
\end{tabular}

${ }^{\mathrm{a}}$ The shallow zone and ACL staging pile footprint values are from the 100-F-20 Cleanup Verification $95 \%$ UCL Calculations, Calculation No. 0100F-CA-V0274, Rev. 0. Refer to Appendix C for additional details on determination of statistical values.

b Represents the 90th percentile of the lognormal distribution (DOE-RL 1996).

$\mathrm{ACL}$ above contaminant level

$\mathrm{ND}=$ not detected (in all samples in the data set)

$\mathrm{COC}=$ contaminant of concern

UCL = upper confidence limit

\subsection{RESRAD MODELING}

A site-specific RESidual RADioactivity (RESRAD) model was not developed for the 100-F-20 waste site. The radionuclide statistical sampling results, shown in Table 2 , meet the remedial action goals summarized in Table 1 as demonstrated using the sum-of-fractions method in Section 5.1.1, below. 


\subsection{EVALUATION OF REMEDIAL ACTION GOAL ATTAINMENT}

This section demonstrates that remedial actions at the 100-F-20 site have achieved the applicable RAGs. Sections 5.1, 5.2, and 5.3 address attainment of direct exposure RAGs, groundwater protection RAGs, and Columbia River protection RAGs, respectively. Section 5.4 documents application of the WAC 173-340 three-part test to the shallow zone and the ACL staging pile footprint. This test is required for nonradionuclide COCs only and is based on the most restrictive RAG for each zone.

\subsection{DIRECT EXPOSURE SOIL REMEDIAL ACTION GOALS ATTAINED}

\subsubsection{Radionuclides}

All of the radionuclide COCs were below the limit of detection in the cleanup verification samples collected for the shallow zone remediation footprint. Cesium-137, nickel-63 and strontium- 90 were detected in the cleanup verification samples for the ACL waste staging pile footprint. The cumulative radionuclide dose for the ACL staging pile footprint was calculated using the sum-of-fractions method shown in Table 3. The columns on the left side of Table 3 are the COCs and the $95 \%$ UCL values. The third column of each table presents the single radionuclide $15 \mathrm{mrem} / \mathrm{yr}$ dose-equivalence activity, and the last column presents the statistical values divided by the doseequivalence activity. The cumulative dose of $0.60 \mathrm{mrem} / \mathrm{yr}$ for the $\mathrm{ACL}$ staging pile footprint is less than the $15 \mathrm{mrem} / \mathrm{yr}$ RAG. Therefore, both the shallow zone decision unit and the ACL staging pile footprint achieve the remedial action goals for direct exposure at the 100-F-20 waste site.

Table 3. Attainment of Radionuclide Direct Exposure RAG for the ACL Staging Pile Footprint.

\begin{tabular}{|l|c|c|c|}
\hline $\begin{array}{c}\text { Contaminants of } \\
\text { Potential Concern }\end{array}$ & $\begin{array}{c}\text { 95\% UCL Value } \\
\text { (pCi/g) }\end{array}$ & $\begin{array}{c}\text { Activity Equivalent } \\
\text { to 15 mrem/yr } \\
\text { Dose (pCi/g) }\end{array}$ & Fraction \\
\hline Cesium-137 & 0.052 & 6.2 & 0.008 \\
\hline Nickel-63 & 1.91 & 4,026 & 0.0005 \\
\hline Strontium-90 & 0.141 & 4.5 & 0.031 \\
\hline \multicolumn{4}{r}{} \\
\hline \multicolumn{3}{r|}{ Equivalent Dose (mrem/yr) } & 0.040 \\
\hline
\end{tabular}

\subsubsection{Nonradionuclides}

5.1.2.1 Direct Comparison to RAGs. Table 4 compares the cleanup verification statistical values presented in Table 2 to the direct exposure RAGs presented in 
Table 1. All residual concentrations are below the direct exposure RAG and, as such, all applicable nonradionuclide RAGs have been met for direct exposure.

Table 4. Attainment of Nonradionuclide Direct Exposure Standards.

\begin{tabular}{|c|c|c|c|}
\hline Nonradionuclides & $\begin{array}{c}\text { Cleanup Verification } \\
\text { Data Set (mg/kg) }\end{array}$ & $\begin{array}{c}\text { Direct Exposure RAG } \\
(\mathrm{mg} / \mathrm{kg})\end{array}$ & $\begin{array}{c}\text { Direct Exposure RAGs } \\
\text { Attained }^{\mathrm{b}}\end{array}$ \\
\hline \multicolumn{4}{|c|}{ Shallow Zone } \\
\hline Lead & 24.1 & $353^{\mathrm{c}}$ & Yes \\
\hline \multicolumn{5}{|c|}{ ACL Staging Pile Footprint } \\
\hline Lead & 18.0 & $353^{\mathrm{c}}$ & Yes \\
\hline
\end{tabular}

" Lookup values and RAGs obtained from the 100 Area RDR/RAWP (DOE-RL 2005) or calculated per WAC 173-340-720, WAC 173-340-730, and WAC 173-340-740, Method B, 1996, unless otherwise noted.

b Criterion is comparison to the cleanup criteria (RAG).

c RAG derived from Guidance Manual for the Integrated Exposure Uptake Biokinetic Model for Lead in Children (EPA 1994).

$\mathrm{ACL} \quad=$ above cleanup level

RAG = remedial action goal

RDR/RAWP = remedial design report/remedial action work plan

WAC $=$ Washington Administrative Code

5.1.2.2 Noncarcinogenic Hazard Quotient RAG Attained. For noncarcinogenic COCs, WAC 173-340-740(5)(a) and (b) specify the evaluation of the hazard quotient, which is given as the daily intake divided by a reference dose (DOE-RL 2005). Lead is the only nonradionuclide $\mathrm{COC}$. The hazard quotient calculation is not required when lead is the only COC because lead does not have a reference dose (RfD) for use in the hazard quotient calculation. This is because the toxic effects of lead are correlated with blood-lead levels rather than exposure levels or daily intake (EPA 1994).

5.1.2.3 Carcinogenic Risk RAG Attained. For individual nonradionuclide carcinogenic COCs, the WAC 173-340 Method B cleanup limits are based on an incremental cancer risk of $1 \times 10^{-6}$. For nonradionuclide carcinogenic COCs, the total excess cancer risk must be less than $1 \times 10^{-5}$ (DOE-RL 2005). There are no carcinogenic nonradionuclide COCs for $100-\mathrm{F}-20$, therefore calculation of the carcinogenic risk is not required.

\subsection{GROUNDWATER REMEDIAL ACTION GOALS ATTAINED}

\subsubsection{Radionuclides}

No radionuclides were detected in the cleanup verification samples for the 100-F-20 shallow zone remediation footprint. Verification sampling detected cesium-137, nickel-63, and strontium-90 in the ACL staging pile footprint. Based on the 100 Area Radionuclide and Nonradionuclide Lookup Values for the 1995 Remedial Action Record of Decision (BHI 2004) and on the 100 Area Analogous Sites RESRAD Calculations 
(BHI 2005), the residual concentrations of the radionuclide COCs in soil are significantly less than the concentrations predicted to cause the $4 \mathrm{mrem} / \mathrm{yr}$ drinking water standard (DOE-RL 2005) to be exceeded. The RESRAD modeling $(\mathrm{BHI} 2004,2005)$ using $\mathrm{K}_{d}$ (distribution coefficient) values of $50 \mathrm{~mL} / \mathrm{g}$ for cesium-137, $30 \mathrm{~mL} / \mathrm{g}$ for nickel-63, and 25 $\mathrm{mL} / \mathrm{g}$ for strontium- 90 , predicts that the residual soil concentrations of these radionuclides at 100-F-20 will be protective of groundwater (and, therefore, the Columbia River) at maximum contaminant levels (MCLs) that meets the $4 \mathrm{mrem} / \mathrm{yr}$ drinking water standard. As such, the soil RAGs for the protection of groundwater have been attained for the shallow zone and $A C L$ staging pile footprint decision units at the 100-F-20 waste site.

\subsubsection{Nonradionuclides}

Table 5 illustrates the comparison of cleanup verification values to the soil RAGs for groundwater protection. The statistical value for lead exceeds the soil RAG for the protection of groundwater in both the shallow zone remediation footprint and in the ACL staging pile footprint. Lead is not predicted to reach groundwater based on RESRAD modeling using its soil partitioning coefficient (BHI 2005). Data were not collected showing the vertical extent of residual lead contamination, but, with a clean zone extending at least $3 \mathrm{~m}(10 \mathrm{ft})$ and a soil-partitioning coefficient of $30 \mathrm{~mL} / \mathrm{g}, \mathrm{RESRAD}$ modeling predicts that lead will not reach groundwater (and, therefore, the Columbia River) in 1,000 years. As such, the nonradionuclide soil RAGS for the protection of groundwater have been attained for the shallow zone and ACL staging pile footprint decision units at the $100-\mathrm{F}-20$ waste site.

Table 5. Attainment of Nonradionuclide Remedial Action Goals for Protection of Groundwater and the Columbia River.

\begin{tabular}{|c|c|c|c|c|c|}
\hline Nonradionuclides & $\begin{array}{c}\text { Cleanup } \\
\text { Verification } \\
\text { Data Set } \\
(\mathrm{mg} / \mathrm{kg})\end{array}$ & $\begin{array}{c}\text { Soil RAG for } \\
\text { Groundwater } \\
\text { Protection } \\
(\mathrm{mg} / \mathrm{kg})\end{array}$ & $\begin{array}{c}\text { Soil RAG for } \\
\text { Columbia River } \\
\text { Protection } \\
(\mathrm{mg} / \mathrm{kg})\end{array}$ & $\begin{array}{c}\text { Groundwater } \\
\text { and/or River } \\
\text { Protection } \\
\text { RAGs } \\
\text { Exceeded? }\end{array}$ & $\begin{array}{c}\text { Does the } \\
\text { Maximum } \\
\text { Result Pass } \\
\text { Modeling? }\end{array}$ \\
\hline \multicolumn{7}{|c|}{ Shallow Zone } \\
\hline Lead & 24.1 & $10.2^{\mathrm{b}}$ & $10.2^{\mathrm{b}}$ & Yes & Yes $^{\mathrm{c}}$ \\
\hline \multicolumn{7}{|c|}{ ACL Staging Pile Footprint } \\
\hline Lead & 18.0 & $10.2^{\mathrm{b}}$ & $10.2^{\mathrm{b}}$ & Yes & Yes $^{\mathrm{c}}$ \\
\hline
\end{tabular}

a Lookup values and RAGs obtained from the 100 Area RDR/RAWP (DOE-RL 2005) or calculated per WAC 173-340-720, WAC 173-340-730, and WAC 173-340-740, Method B, 1996, unless otherwise noted.

b Where cleanup levels are less than background, cleanup levels default to background (WAC 173-340-700[4][d]) (1996).

c Based on 100 Area Analogous Sites RESRAD Calculations (BHI 2005), and a Kd value of $30 \mathrm{~mL} / \mathrm{g}$, lead is not expected to migrate more than $3 \mathrm{~m}(10 \mathrm{ft})$ vertically in 1,000 years $(\mathrm{BHI} 2005)$.

$\mathrm{ACL} \quad=$ above cleanup level

RAG = remedial action goal

RESRAD = RESidual RADioactivity (dose model)

RDR/RAWP = remedial design report/remedial action work plan

WAC $\quad=$ Washington Administrative Code 
Although not COCs, the full list of ICP metals were analyzed in the verification samples collected from the ACL staging pile footprint. Copper and zinc were detected in the ICP analysis; however, they were detected at concentrations that were within the range of natural Hanford Site background levels (DOE-RL 1996). Therefore, they require no further evaluation and do not pose a threat to groundwater or the Columbia River.

\subsection{COLUMBIA RIVER REMEDIAL ACTION GOALS ATTAINED}

\subsubsection{Radionuclides}

The river protection RAGs for radionuclides are identical to the groundwater protection RAGs. The results indicated that radionuclides are not predicted to reach groundwater (and, by extension, not predicted to reach the Columbia River) at levels that would cause the $4 \mathrm{mrem} / \mathrm{yr}$ drinking water standard (DOE-RL 2005) to be exceeded. Therefore, the Columbia River protection RAGs have been attained.

\subsubsection{Nonradionuclides}

Table 5 illustrates the comparison of cleanup verification statistical values to the soil RAGs for protection of the Columbia River. The statistical value for lead exceeds the soil RAG for the protection of the Columbia River in both the shallow zone remediation footprint and in the ACL staging pile footprint. Lead is not predicted to reach groundwater (and, therefore, the Columbia River) based on RESRAD modeling using the lead soil partitioning coefficient (BHI 2005). Data were not collected showing the vertical extent of residual lead contamination, but, with a clean zone extending at least 3 $\mathrm{m}(10 \mathrm{ft})$ and a soil-partitioning coefficient $30 \mathrm{~mL} / \mathrm{g}$, RESRAD predicts that lead will not reach groundwater and, therefore, the Columbia River in 1,000 years. As such, the soil RAGs for the protection of the Columbia River have been attained for the shallow zone and ACL staging pile footprint at the $100-F-20$ waste site.

Although not COCs, the full list of ICP metals were analyzed in the verification samples collected from the ACL staging pile footprint. Copper and zinc were detected in the ICP analysis; however, they were detected at concentrations that were within the range of natural Hanford Site background levels (DOE-RL 1996). Therefore, they require no further evaluation and do not pose a threat to groundwater or the Columbia River.

\subsection{WAC 173-340 THREE-PART TEST FOR NONRADIONUCLIDES}

Sections 5.1, 5.2, and 5.3 look separately at compliance with direct exposure RAGs, groundwater protection soil RAGs, and Columbia River protection soil RAGs.

Section 5.4 documents application of the WAC 173-340 three-part test for nonradionuclides using the most restrictive RAGs applicable to each decision unit (i.e., shallow zone and ACL staging pile footprint). The most restrictive RAG is defined as the lowest of the direct exposure, groundwater protection, and river protection RAGs. The direct exposure, groundwater protection, and river protection RAGs are applicable 
to the shallow zone and ACL staging pile footprint. The WAC 173-340 three-part test consists of the following criteria: (1) the cleanup verification statistical value must be less than the cleanup level, (2) no single detection can exceed two times the cleanup criteria, and (3) the percentage of samples exceeding the cleanup criteria must be less than $10 \%$.

Table 6 summarizes the results of the WAC 173-340 three-part test (WAC 173-340-740[7]) for the shallow zone and ACL staging pile footprint sample data sets. For lead, the table lists the most restrictive applicable RAG (selected from the RAGs in Table 1), the maximum detected value, the total number of samples collected, and the number of samples exceeding the most restrictive RAG. The final column of the table describes the result of applying the three WAC 173-340 criteria using the values listed in the preceding columns. Table 6 shows that lead passes the WAC 173-340 three-part test for all data sets.

Table 6. Application of the WAC 173-340 Three-Part Test. (2 Pages)

\begin{tabular}{|c|c|c|c|c|c|c|}
\hline Nonradionuclides & $\begin{array}{c}\text { Most } \\
\text { Stringent } \\
\text { Applicable } \\
\text { RAG } \\
(\mathrm{mg} / \mathrm{kg})\end{array}$ & $\begin{array}{c}\text { Statistical } \\
\text { Value } \\
(\mathrm{mg} / \mathrm{kg})^{\mathrm{a}}\end{array}$ & $\begin{array}{c}\text { Maximum } \\
\text { Detected } \\
\text { Value } \\
(\mathrm{mg} / \mathrm{kg})^{\mathrm{b}}\end{array}$ & $\begin{array}{c}\text { Total } \\
\text { Number } \\
\text { of } \\
\text { Samples }^{\mathrm{c}}\end{array}$ & $\begin{array}{c}\text { Number } \\
\text { Exceeding } \\
\text { Criteria }^{\mathrm{d}}\end{array}$ & $\begin{array}{c}\text { RAGs } \\
\text { Attained? } \\
\text { (Yes/No) }\end{array}$ \\
\hline \multicolumn{7}{|c|}{ Shallow Zone } \\
\hline Lead & $10.2^{\mathrm{e}}$ & 24.1 & 31.2 & 5 & 4 & Yes $^{\mathrm{f}}$ \\
\hline \multicolumn{6}{|c|}{ ACL Staging Pile Footprint } & Yes $^{\mathrm{f}}$ \\
\hline
\end{tabular}

a Criterion is comparison to the cleanup criteria (RAG).

- Criterion is no single detection can exceed two times the cleanup criteria.

c The total number of samples includes field duplicate samples, which are included in the evaluation as separate samples.

d Criterion is the percentage of samples exceeding the cleanup criteria must be less than $10 \%$.

e Where cleanup levels are less than background, cleanup levels default to background (WAC 173-340-700[4][d]) (1996).

$f$ Lead does not meet all three criteria of the WAC 173-340 three part test for the shallow zone and ACL staging pile footprint. However, because lead has a distribution coefficient value of $30 \mathrm{~mL} / \mathrm{g}$, an evaluation based on the 100 Area Analogous Sites RESRAD Calculations (BHI 2005) shows that lead will not reach groundwater (and, therefore, the Columbia River) within 1,000 years.

$\mathrm{ACL}=$ above contaminant levels

RAG = remedial action goal

WAC $=$ Washington Administrative Code

\subsection{STATEMENT OF PROTECTIVENESS}

This cleanup verification package demonstrates that remedial action at the 100-F-20 site has achieved the remedial action objectives and corresponding RAGs established in the ROD (EPA 2000) and RDR/RAWP (DOE-RL 2005). The contaminated materials from the site have been excavated and disposed of at ERDF. The remaining soils at the 100-F-20 site have been sampled, analyzed, and evaluated. The results of this effort indicate that residual concentrations will support future land uses that can be 
represented (or bounded) by a rural-residential scenario and that residual concentrations throughout the site pose no threat to groundwater or the Columbia River. This site has no deep zone; therefore, no institutional controls are required. The $100-\mathrm{F}-20$ site is verified to be remediated in accordance with the ROD (EPA 2000) and may be backfilled.

\subsection{REFERENCES}

40 CFR 141, "National Primary Drinking Water Regulations," Code of Federal Regulations, as amended.

65 FR 76708, "National Primary Drinking Water Regulations; Radionuclides; Final Rule," Federal Register, Vol. 65, No. 236, p. 76708, December 7, 2000.

BHI, 1995, Geophysical Investigations of the 100-F-1 Depression, 100-F-14 Vent Pipe, PNL Parallel Pits, 100-FR-2 Operable Unit, BHI-00343, Rev. 0, Bechtel Hanford, Inc., Richland, Washington.

BHI, 2001, Calculation of Total Uranium Activity Corresponding to a Maximum Contaminant Level for Total Uranium of 30 Micrograms per Liter in Groundwater, 0100X-CA-V0038, Rev. 0, Bechtel Hanford, Inc., Richland, Washington.

BHI, 2004, 100 Area Radionuclide and Nonradionuclide Lookup Values for the 1995 Interim Remedial Action Record of Decision, 0100X-CA-V0046, Rev. 0, Bechtel Hanford, Inc., Richland, Washington

BHI, 2005, 100 Area Analogous Sites RESRAD Calculations, 0100X-CA-V0050, Rev. 0, Bechtel Hanford, Inc., Richland, Washington.

DOE Order 5400.5, Radiation Protection of the Public and the Environment, as amended, U.S. Department of Energy, Washington, D.C.

DOE-RL, 1996, Hanford Site Background: Part 2, Soil Background for Radionuclides, DOE/RL-96-12, Rev. 0, Richland, U.S. Department of Energy, Richland Operations Office, Richland, Washington.

DOE-RL, 1998, Tri-Party Agreement Handbook Management Procedures, RL-TPA-90-0001, Guideline Number TPA-MP-14, "Maintenance of the Waste Information Data System (WIDS)," U.S. Department of Energy, Richland Operations Office, Richland, Washington.

DOE-RL, 2001, 100 Area Burial Grounds Remedial Action Sampling and Analysis Plan, DOE/RL-2001-35, Rev. 0, U.S. Department of Energy, Richland Operations Office, Richland, Washington. 
DOE-RL, 2005, Remedial Design Report/Remedial Action Work Plan for the 100 Area, DOE/RL-96-17, Rev. 5, U.S. Department of Energy, Richland Operations Office, Richland, Washington.

Ecology, EPA, and DOE, 1989, Hanford Federal Facility Agreement and Consent Order, 2 vols., as amended, Washington State Department of Ecology,

U.S. Environmental Protection Agency, and U.S. Department of Energy, Olympia, Washington.

EPA, 1994, Guidance Manual for the Integrated Exposure Uptake Biokinetic Model for Lead in Children, EPA/540/R-93/081, Publication No. 9285.7, U.S. Environmental Protection Agency, Washington, D.C.

EPA, 2000, Record of Decision for the 100-BC-1, 100-BC-2, 100-DR-1, 100-DR-2, 100-FR-2, 100-HR-2, and 100-KR-2 Operable Units, Hanford Site (100 Area Burial Grounds), Benton County, Washington, U.S. Environmental Protection Agency, Region 10, Seattle, Washington.

WAC 173-340, 1996, "Model Toxics Control Act - Cleanup," Washington Administrative Code.

WCH, 2006, "100-F Field Remediation Cleanup Verification," Meeting Minutes to Distribution from S. W. Callison, CCN 127646, dated May 10, 2006, Washington Closure Hanford, Richland, Washington. 
CVP-2006-00009

Rev. 0 
CVP-2006-00009

Rev. 0

\section{APPENDIX A}

\section{SUMMARY OF VERIFICATION SOIL SAMPLING RESULTS FOR THE 100-F-20 WASTE SITE COCs}


CVP-2006-00009

Rev. 0

A-ii 
100-F-20 Shallow Zone Verification Sampling Results. (2 Pages)

\begin{tabular}{|c|c|c|c|c|c|c|c|c|c|c|c|c|c|c|}
\hline \multirow{2}{*}{$\begin{array}{c}\text { Sample } \\
\text { Location }\end{array}$} & \multirow{2}{*}{$\begin{array}{l}\text { Sample } \\
\text { Number }\end{array}$} & \multirow{2}{*}{$\begin{array}{c}\text { Sample } \\
\text { Date }\end{array}$} & \multicolumn{3}{|c|}{ Cesium-137 } & \multicolumn{3}{|c|}{ Cobalt-60 } & \multicolumn{3}{|c|}{ Nickel-63 } & \multicolumn{3}{|c|}{ Plutonium-239/240 } \\
\hline & & & $\mathrm{pCi} / \mathrm{g}$ & $\mathbf{Q}$ & MDA & $\mathrm{pCi} / \mathrm{g}$ & $\mathbf{Q}$ & MDA & $\mathrm{pCi} / \mathrm{g}$ & $\mathbf{Q}$ & MDA & $\mathrm{pCi} / \mathrm{g}$ & $\mathbf{Q}$ & MDA \\
\hline A1 & $\mathrm{J} 135 \mathrm{~B} 2$ & $8 / 16 / 06$ & 0.051 & $U$ & 0.051 & 0.053 & U & 0.053 & -0.496 & U & 3.4 & 0.047 & U & 0.089 \\
\hline $\mathrm{A} 2$ & J135B4 & $8 / 16 / 06$ & 0.019 & $U$ & 0.019 & 0.019 & U & 0.019 & -1.43 & U & 3.4 & 0.020 & U & 0.064 \\
\hline A3 & J135B5 & $8 / 16 / 06$ & 0.048 & U & 0.048 & 0.046 & U & 0.046 & -0.326 & U & 3.4 & -0.004 & U & 0.043 \\
\hline $\mathrm{A} 4$ & J135B6 & $8 / 16 / 06$ & 0.032 & $\mathrm{U}$ & 0.032 & 0.031 & $\mathrm{U}$ & 0.031 & -1.17 & $\mathrm{U}$ & 3.4 & 0.007 & $\mathrm{U}$ & 0.051 \\
\hline $\begin{array}{c}\text { Duplicate of } \\
\text { J135B2 }\end{array}$ & J135B3 & $8 / 16 / 06$ & 0.042 & U & 0.042 & 0.041 & U & 0.041 & 0.429 & U & 3.6 & 0.011 & U & 0.042 \\
\hline $\begin{array}{l}\text { Split of } \\
\mathrm{J} 135 \mathrm{~B} 2\end{array}$ & J135B7 & $8 / 16 / 06$ & 0.019 & U & 0.021 & -0.009 & U & 0.020 & 1.29 & $U$ & 1.44 & 0.015 & U & 0.041 \\
\hline
\end{tabular}

\begin{tabular}{|c|c|c|c|c|c|c|c|c|}
\hline Sample & Sample & Sample & \multicolumn{3}{|c|}{ Strontium-90 } & \multicolumn{3}{|c|}{ Lead } \\
\cline { 5 - 9 } Location & Number & Date & pCi/g & Q & MDA & mg/kg & Q & PQL \\
\hline A1 & J135B2 & $8 / 16 / 06$ & 0.065 & $\mathrm{U}$ & 0.22 & 10.9 & & 0.30 \\
\hline A2 & J135B4 & $8 / 16 / 06$ & 0.012 & $\mathrm{U}$ & 0.27 & 3.8 & & 0.30 \\
\hline A3 & J135B5 & $8 / 16 / 06$ & 0.074 & $\mathrm{U}$ & 0.23 & 11.4 & & 0.30 \\
\hline A4 & J135B6 & $8 / 16 / 06$ & 0.071 & $\mathrm{U}$ & 0.22 & 31.2 & & 0.31 \\
\hline $\begin{array}{c}\text { Duplicate of } \\
\text { J135B2 }\end{array}$ & $\mathrm{J} 135 \mathrm{~B} 3$ & $8 / 16 / 06$ & 0.03 & $\mathrm{U}$ & 0.23 & 11.9 & & 0.3 \\
\hline $\begin{array}{c}\text { Split of } \\
\text { J135B2 }\end{array}$ & $\mathrm{J} 135 \mathrm{~B} 7$ & $8 / 16 / 06$ & 0.09 & $\mathrm{U}$ & 0.13 & 11.4 & & 0.15 \\
\hline
\end{tabular}

Note: The following abbreviations apply to all Appendix A tables.

$\mathrm{ACL}=$ above cleanup levels

MDA = minimum detectable activity

$\mathrm{Q}=$ qualifier

$\mathrm{PQL}=$ practical quantitation limit 
100-F-20 ACL Staging Pile Footprint Verification Sampling Results. (2 Pages)

\begin{tabular}{|c|c|c|c|c|c|c|c|c|c|c|c|c|c|c|}
\hline \multirow{2}{*}{$\begin{array}{l}\text { Sample } \\
\text { Location }\end{array}$} & \multirow{2}{*}{$\begin{array}{l}\text { Sample } \\
\text { Number }\end{array}$} & \multirow{2}{*}{$\begin{array}{c}\text { Sample } \\
\text { Date }\end{array}$} & \multicolumn{3}{|c|}{ Cesium-137 } & \multicolumn{3}{|c|}{ Cobalt-60 } & \multicolumn{3}{|c|}{ Nickel-63 } & \multicolumn{3}{|c|}{ Plutonium-239/240 } \\
\hline & & & $\mathrm{pCi} / \mathrm{g}$ & $\mathbf{Q}$ & MDA & $\mathrm{pCi} / \mathrm{g}$ & $\mathbf{Q}$ & MDA & $\mathrm{pCi} / \mathrm{g}$ & $\mathbf{Q}$ & MDA & $\mathrm{pCi} / \mathrm{g}$ & $\mathbf{Q}$ & MDA \\
\hline $\mathrm{A} 1$ & J135W1 & $8 / 31 / 06$ & 0.032 & $\mathrm{U}$ & 0.032 & 0.036 & $U$ & 0.036 & 0.814 & $\mathrm{U}$ & 3.30 & 0.00 & $U$ & 0.380 \\
\hline A2 & J135W2 & $8 / 31 / 06$ & 0.046 & $U$ & 0.046 & 0.041 & $U$ & 0.041 & 0.085 & $U$ & 3.50 & 0.00 & $U$ & 0.240 \\
\hline $\mathrm{A} 3$ & J135W4 & $8 / 31 / 06$ & 0.120 & $\mathrm{U}$ & 0.120 & 0.140 & $\mathrm{U}$ & 0.140 & 1.04 & $\mathrm{U}$ & 3.50 & 0.00 & $\bar{U}$ & 0.240 \\
\hline $\mathrm{A} 4$ & J135W5 & $8 / 31 / 06$ & 0.044 & & 0.026 & 0.028 & $\mathrm{U}$ & 0.028 & 1.04 & $\bar{U}$ & 3.50 & 0.00 & $U$ & 0.350 \\
\hline $\begin{array}{c}\text { Duplicate of } \\
\text { J135W2 }\end{array}$ & J135W3 & $8 / 31 / 06$ & 0.042 & $U$ & 0.042 & 0.046 & $U$ & 0.046 & 4.68 & & 3.70 & 0.172 & $U$ & 0.260 \\
\hline $\begin{array}{c}\text { Split of } \\
\text { J135W2 }\end{array}$ & J135W6 & $8 / 31 / 06$ & 0.044 & & 0.018 & 0.002 & $U$ & 0.020 & -0.141 & $U$ & 10.8 & & & \\
\hline
\end{tabular}

\begin{tabular}{|c|c|c|c|c|c|c|c|c|}
\hline \multirow{2}{*}{$\begin{array}{c}\text { Sample } \\
\text { Location }\end{array}$} & \multirow{2}{*}{$\begin{array}{l}\text { Sample } \\
\text { Number }\end{array}$} & \multirow{2}{*}{$\begin{array}{c}\text { Sample } \\
\text { Date }\end{array}$} & \multicolumn{3}{|c|}{ Strontium-90 } & \multicolumn{3}{|c|}{ Lead } \\
\hline & & & $\mathrm{pCi} / \mathrm{g}$ & $\mathbf{Q}$ & MDA & $\mathrm{mg} / \mathrm{kg}$ & $\mathbf{Q}$ & $P Q L$ \\
\hline $\mathrm{A} 1$ & J135W1 & $8 / 31 / 06$ & -0.042 & $U$ & 0.220 & 17.7 & & 0.36 \\
\hline A2 & J135W2 & $8 / 31 / 06$ & 0.159 & $U$ & 0.250 & 8.4 & & 0.35 \\
\hline $\mathrm{A} 3$ & J135W4 & $8 / 31 / 06$ & -0.045 & $\mathrm{U}$ & 0.230 & 3.5 & & 0.37 \\
\hline $\mathrm{A} 4$ & J135W5 & $8 / 31 / 06$ & 0.041 & U & 0.240 & 18.5 & & 0.34 \\
\hline $\begin{array}{l}\text { Duplicate of } \\
\text { J135W2 }\end{array}$ & J135W3 & $8 / 31 / 06$ & 0.265 & & 0.230 & 7.6 & & 0.35 \\
\hline $\begin{array}{c}\text { Split of } \\
\text { J135W2 }\end{array}$ & J135W6 & $8 / 31 / 06$ & 0.0426 & $U$ & 0.136 & 6.8 & & 0.15 \\
\hline
\end{tabular}


CVP-2006-00009

Rev. 0

APPENDIX B

\section{DATA QUALITY ASSESSMENT}

B-i 
CVP-2006-00009

Rev. 0

B-ii 


\section{B1.0 DATA QUALITY ASSESSMENT FOR THE 100-F-20 PNL PARALLEL PITS}

\section{B1.1 OVERVIEW}

The data quality assessment (DQA) completes the data life cycle (i.e., planning, implementation, and assessment) that was initiated by the data quality objectives process. The DQA includes a review of the field logbook information (WCH 2006) to verify sample location, date, and time. It also involves a scientific and statistical evaluation of the data to determine if they are of the right type, quality, and quantity to support their intended use for closeout decisions (EPA 2000).

This DQA was performed in accordance with data quality objectives found in the 100 Area Burial Grounds Remedial Action Sampling and Analysis Plan (SAP) (DOE-RL 2001). The DQA is based on the guidelines presented in Guidance for Data Quality Assessment (EPA 2000). Statistical tests used in this DQA were performed as specified in the SAP and the Remedial Design Report/Remedial Action Work Plan for the 100 Area (RDR/RAWP) (DOE-RL 2005). Waste site COCs were identified in the SAP (DOE-RL 2001) and included cobalt-60, strontium-90, and plutonium-239/240. Cesium-137 and lead were detected above background in the in-process soil samples and were, therefore, added as waste site COCs. Additionally, nickel-63 was added as a $\mathrm{COC}$ because of a single detection in the cleanup verification samples for the abovecleanup-level $(A C L)$ staging pile footprint.

Prior to performing statistical tests, the field logbook (WCH 2006), the sample design (Appendix C), and the sample analytical data are evaluated. A portion of the cleanup verification sample analytical data is validated for compliance requirements (DOE-RL 2001). An evaluation is performed to determine if the laboratory carried out all steps required by the SAP and the laboratory contract governing the conduct of analysis and reporting of the data. Data validation, in accordance with validation procedures specified in Data Validation Procedure for Chemical Analysis (BHI 2000a) and in Data Validation Procedure for Radiochemical Analysis (BHI 2000b), is performed as part of data evaluation. After validation and data evaluation, the appropriate statistical analyses are performed on the analytical data (Appendix $\mathrm{C}$ ) to determine statistical values, as appropriate, for each contaminant. The cleanup verification sample analytical data are stored in the Environmental Restoration (ENRE) project-specific database prior to being submitted for inclusion in the Hanford Environmental Information System (HEIS) database and are summarized in Appendix A, as well.

\section{B1.2 LABORATORY QUALITY MEASURES}

All verification samples are subject to laboratory-specific quality assurance (QA) requirements, including instrument procurement, maintenance, calibration, and 
operation. Additional laboratory quality control (QC) checks are performed, as appropriate, for the analytical method at a rate of 1 per SDG, or 1 per 20 samples, whichever is more frequent. Laboratory internal QC checks include the following:

- Laboratory Contamination. Each analytical batch contains a laboratory (method) blank (material of similar composition as the samples with known/minimal concentrations of the analytes of interest) carried through the complete analytical process. The method blank is used to evaluate samples for false-positive results due to contamination at the laboratory.

- Analytical Accuracy. For most analyses, a known quantity of representative analytes of interest are added to a separate aliquot of a sample from the analytical batch, known as the matrix spike/matrix spike duplicate (MS/MSD). The recovery percentages of the added MS are used to evaluate analytical accuracy. For analyses not amenable to MS techniques (e.g., gamma energy analysis) or where analytical recovery is corrected via internal standards (e.g., alpha spectral analyses), accuracy is evaluated from recovery of the $\mathrm{QC}$ reference sample (i.e., laboratory control sample [LCS] or blank spike sample).

- Analytical Precision. Separate aliquots removed from the same sample container (replicate samples) are analyzed for each analytical batch, and referred to as the laboratory duplicate or replicate. The replicate sample results (evaluated as relative percent differences [RPDs]) are used to assess the analytical precision achieved at the laboratory. However, natural heterogeneities often found in soil matrix samples, are also added into the RPD calculation.

- QC Reference Samples. A QC reference sample is prepared from an independent standard at a concentration other than that used for calibration, but within the calibration range. Reference samples provide an independent check on analytical technique and methodology.

Laboratories are also subject to periodic and random assessments of the laboratory performance, systems, and overall program. These assessments are performed by the Washington Closure Hanford QA group to ensure that the laboratories are performing within laboratory contract requirements.

\section{B1.3 DATA VALIDATION}

After sampling and analysis, all of the fixed laboratory data from SDG K0541 were submitted for third-party validation to Level $\mathrm{C}$ validation procedures. Level $\mathrm{C}$ validation procedures are specified in Data Validation Procedure for Radiochemical Analysis (BHI 2000b) and Data Validation Procedure for Chemical Analysis (BHI 2000a).

Level $\mathrm{C}$ validation procedures were used to review and qualify the data for the following parameters: 
- Sample holding times

- Method blanks

- MS/MSD recovery

- Surrogate recovery

- Sample replicates (duplicates)

- Laboratory control sample results

- Data package completeness

- Achievement of required detection limits (RDLs) or contract required quantitation limits (CRQLs)

Data qualified as rejected (i.e., " $R$ " flagged) indicate that the associated analytical result is tainted by a major deficiency in the quality of the data. Rejected data are unsuitable for decision-making purposes. Data qualified as estimated (i.e., "J" flagged) indicate that the data is estimated, but may be used for decision-making purposes. Data qualified as undetected (i.e., "U" flagged) indicate that the analyte was analyzed for, but was not detected. For nonradionuclides, nondetected data are reported at the practical quantitation limit (PQL). For radionuclides, nondetected data are reported at the actual value obtained from analysis (positive or negative but less than the minimum detectable activity [MDA]), except for limited analyses where no value can be calculated and the analytes are reported nondetected at the MDA. All other validated results are considered accurate within the standard errors associated with the methods.

The adequacy of laboratory QA/QC was evaluated for precision, accuracy, completeness, and RDLs pursuant to the SAP (DOE-RL 2001). The organization performing the data validation reported that, of the data given formal validation, the laboratory met the standards of performance for precision $( \pm 30 \%)$, accuracy $( \pm 30 \%)$, and completeness (>90\%).

\section{SDG K0541}

This data package comprises five samples (J135W1, J135W2, J135W3, J135W4, $\mathrm{J} 135 \mathrm{~W} 5$ ) analyzed by inductively coupled plasma (ICP) analysis, nickel-63 analysis, total strontium analysis, isotopic plutonium analysis, and gamma spectroscopy. All five samples were collected from the 100-F-20 waste staging pile footprint. Sample J135W2 (A2) is the main sample and sample J135W3 is the corresponding field duplicate. SDG K0541 was evaluated through a formal third-party validation process. A summary of the validation follows:

No equipment blank was collected for this site. There is no impact on the field sample data; no qualification was applied.

Radionuclides. No major or minor deficiencies were found in the SDG K0541 radiological data.

Nonradionuclides. No major deficiencies were found in the SDG K0541 nonradiological data. Minor deficiencies are as follows: 
- The ICP metals analysis LCS recovery for silicon is below the acceptance criteria at $46 \%$. Third-party validation qualified all of the silicon data in SDG K0541 as estimated with "J" flags due to the LCS result. Estimated data are useable for decision-making purposes.

- The ICP metals analysis MS recoveries for antimony and lead are outside of the acceptance criteria ( $75 \%$ to $125 \%$ ) at $59.1 \%$ and $144.8 \%$, respectively. Third-party validation qualified all of the antimony and lead data in SDG K0541 as estimated with "J" flags. Estimated data are useable for decision-making purposes.

- The ICP metals analysis MS recoveries for aluminum, iron, magnesium, lead, antimony, and silicon were outside the acceptance criteria range. Because MSs are prepared using field sample matrix, and the composition of the sample matrix is not known ahead of time, it is common for the spike concentration(s) to be insignificant for some analytes compared to the sample matrix concentrations. To confirm quantitation of these analytes, post-digestion spikes (PDSs) are prepared and serial dilutions are performed. The PDS recoveries for these analytes were all acceptable, in the range of $94.7 \%$ to $102.5 \%$, with the exception of antimony (where the spike concentration was similar to the sample matrix concentration, see above), no qualifiers were added to the remaining analytes. The data are useable for decisionmaking purposes.

- Low concentration detections within the method blank (MB) are common for the ICP metals analysis. The analytes calcium, cadmium, chromium, molybdenum, silicon, and zinc were detected at low concentrations. Most of these detections are insignificant compared to the concentrations observed in the samples, and no qualification is applied. When the MB concentration is within 5 times the sample concentration, the analyte is considered estimated and a " $\mathrm{J}$ " flag is applied. Third-party validation qualified all of the detected cadmium data in SDG K0541 as undetected with "UJ" flags. The molybdenum data in samples J135W2, J135W3, $\mathrm{J} 135 \mathrm{~W} 4$, and J135W5, were qualified as undetected and flagged "UJ". These qualifiers point to similarly low concentration detections of these analytes in the samples and the method blank. The data are useable for decision-making purposes.

Limited, random, or sample matrix-specific influenced batch QC issues such as these are a potential challenge for any analysis. The number and types observed in this data set are within expectations for the matrix types and analyses performed. All of the data in SDG K0541 are useable for decision-making purposes.

\section{B1.4 LABORATORY DATA EVALUATION}

The following paragraphs include a data evaluation of the remaining verification sample SDGs (K0525, J00093, J00096) for the 100-F-20 waste site. Comments on the comparability of the samples to the project splits are presented in Section B1.5. 


\section{SDG K0525}

This data set comprises five field samples (J135B2, J135B3, J135B4, J135B5, J135B6). All five samples were collected from the shallow zone excavation at the $100-\mathrm{F}-20$ site. Sample J135B2 (A1) is the main sample and sample J135B3 is the corresponding field duplicate.

Radionuclides. No major or minor deficiencies were found in the SDG K0525 radiological data.

Nonradionuclides. No major deficiencies were found in the SDG K0525 nonradiological data. Minor deficiencies are as follows:

- In the ICP metals analysis, the RPD - for the analyte lead - in the laboratory duplicate is $43.2 \%$. Because the duplicate is prepared from actual field sample matrix (soil), the heterogeneities within the matrix contribute to the RPD result. This deficiency does not indicate a problem with the analytical laboratory methodology. The data are useable for decision making purposes.

\section{SDG J00093}

This data set comprises one field sample (J135B7). Sample J135B7 is the project split of sample J135B2 (A1).

Radionuclides. No major deficiencies were found in the SDG J00093 radiological data. Minor deficiencies are as follows:

- An insufficient sample was given to the laboratory to prepare a laboratory duplicate for the gamma spectroscopy analysis. As an alternative, sample J135B7 was analyzed, with good results, on two separate systems. This is acceptable and the data are useable for decision-making purposes.

- The samples arrived at the laboratory above the sample acceptance criteria temperature. This deficiency will have no effect on the radiological analyses. The data are useable for decision-making purposes.

Nonradionuclides. No major deficiencies were found in the SDG J00093 radiological data. Minor deficiencies are as follows:

- The samples arrived at the laboratory above the sample acceptance criteria temperature. This deficiency will have no effect on the nonradiological analyses specified for SDG J00093. The data are useable for decision-making purposes.

\section{SDG J00096}

This data set comprises one field sample (J135W6). Sample J135W6 is the project split of sample J135W2 (ACL A2). 
Radionuclides. No major or minor deficiencies were found in the SDG J00096 radiological data.

Nonradionuclides. No major deficiencies were found in the SDG J00096 radiological data. Minor deficiencies are as follows:

- The analyte boron was detected at similar concentrations in the MB $(1.6 \mathrm{mg} / \mathrm{kg})$ and in sample J135W2 $(4.5 \mathrm{mg} / \mathrm{kg})$. The project has qualified the boron data for sample J135W2 as estimated, with a "J" flag. Estimated data are useable for decisionmaking purposes.

- Other low level concentrations (calcium, potassium, silicon, sodium), detected in the ICP metals analysis MB, were insignificant compared to the analogous field sample concentrations. No qualification was applied. The data are useable for decisionmaking purposes.

\section{B1.4.1 MAJOR DEFICIENCIES}

Any data anomaly that causes final data to be qualified as rejected (" $R$ " flagged) is considered a major deficiency. No major deficiencies were found the 100-F-20 verification data set.

\section{B1.4.2 MINOR DEFICIENCIES}

Sample Holding Times. All of the method-specific holding times were met for all samples in the 100-F-20 verification data set.

Method Blanks. The method blank is used to evaluate false-positive results in samples due to possible contamination during handling at the laboratory.

Radionuclides. All of the radionuclide method blank results were within the acceptance criteria.

Nonradionuclides. A minor method blank deficiency was identified in SDG J00096 (see above).

MS/MSDs Recoveries. The recovery of spiked analytes in the MS/MSD pair(s) is used to evaluate method efficiency and the effect of the sample matrix on the environmental sample results.

Radionuclides. All MS/MSD recoveries for radionuclide analytes were within acceptance criteria.

Nonradionuclides. A minor deficiency in the MS/MSD recovery is identified in SDG K0541. Some data are qualified as estimated. Estimated data are useable for decisionmaking purposes. 
RDL Comparison. Reported analytical detection levels for nondetected analytes were compared to the RDLs specified in the SAP (DOE-RL 2001). When detected results were obtained, evaluation of detection limits was not performed.

Radionuclides. All of the reported COC MDAs are sufficiently low for decision-making purposes. All values meet the site cleanup criteria as demonstrated in the calculation briefs (Appendix $\mathrm{C}$ ) and discussed in this cleanup verification package.

Nonradionuclides. All of the reported MDLs are sufficiently low for decision-making purposes. All values meet the site cleanup criteria as discussed in this cleanup verification package.

Precision and Accuracy Evaluation. An RPD evaluation of the main sample versus the laboratory duplicate is routinely performed by the laboratory and any deficiencies in the calculations are reported by SDG in Section B1.4.0.

\section{B1.5 FIELD QUALITY ASSURANCE/QUALITY CONTROL}

Field QA/QC measures were used to assess potential sources of error and cross contamination of soil samples that could bias results. Field QA/QC samples listed in the field logbook (WCH 2006) are summarized in Table B-1. The main and QA/QC sample results are presented in Appendix $A$.

Table B-1. Summary of Field Quality Control Samples.

\begin{tabular}{|c|c|c|c|}
\hline Sample & Main & Duplicate & Project-split \\
\hline Shallow zone A1 & J135B2 & J135B3 & J135B7 \\
\hline $\begin{array}{c}\text { Waste staging pile } \\
\text { footprint A2 }\end{array}$ & J135W2 & J135W3 & J135W6 \\
\hline
\end{tabular}

Field duplicate samples are collected to provide a degree of local heterogeneity in the sampling medium, unlike laboratory duplicates that are used to evaluate precision in the analytical process. The field duplicates are evaluated by computing the RPD of the duplicate samples for each COC. Only analytes with values above five times the detection limits for both the main and duplicate samples are compared. The $95 \%$ upper confidence limit (UCL) calculation brief in Appendix $C$ provides details on duplicate pair evaluation and RPD calculation. The data are suitable for the intended purpose of cleanup verification.

Split samples are collected to provide a relative measure of the degree of variability in the sampling, sample handling, and analytical techniques used by commercial laboratories. The field main and split samples are evaluated by computing the RPD of the split samples for each $\mathrm{COC}$ to determine the usability of the verification data. The 
U.S. Environmental Protection Agency Contract Laboratory Program duplicate sample comparison methodology, USEPA Contract Laboratory Program National Functional Guidelines for Inorganic Data Review (EPA 1994), is used as an initial test of the data from the splits. Only analytes that had values above five times the contractual RDL for both the main and split sample were compared. The $95 \%$ UCL calculation briefs in Appendix $\mathrm{C}$ provide details on split pair RPD calculation. The acceptance criteria RPD for project-split samples is $\leq 30 \%$.

Radionuclides. The RPDs calculated for potassium- 40 and radium-226 in the shallow zone A1 duplicate are above the acceptance criteria $(30 \%)$ at $66.7 \%$ and $54.5 \%$, respectively. Elevated RPDs, such as these, in the analysis of environmental soil samples, are largely attributed to heterogeneities in the soil matrix and only in small part attributed to precision and accuracy issues at the laboratory. The data are useable for decision-making purposes.

Nonradionuclides. The RPD calculated for silicon in the project-split of the ACL stockpile sample is $43.3 \%$. This result is also largely attributed to heterogeneities in the soil matrix, and only in small part attributed to precision and accuracy issues at the laboratory. The data are useable for decision-making purposes.

RPDs for the remaining nonradionuclide analytes were either within the acceptance criteria or were not calculated. This is because an evaluation of the data shows the analytes were not detected in both the main and duplicate (or main and split) sample at more than 5 times the target detection limit. RPDs of analytes detected at low concentrations (less than five times the detection limit) are not considered indicative of the analytical system performance. The data are useable for decision-making purposes.

A secondary check of the data variability is used when one or both of the samples being evaluated (main and duplicate or main and split) is less than 5 times the target detection limit (TDL), including undetected analytes. In these cases, a control limit of \pm 2 times the TDL is used (Appendix $C$ ) to indicate that a visual check of the data is required by the reviewer. None of the 100-F-20 samples required this specific check. A visual inspection of all of the data is also performed. No major deficiencies were noted. The data are useable for decision-making purposes.

\section{B1.6 SUITABILITY OF DATA}

The DQA for the 100-F-20 waste site determined that the data are of the correct type, quality, and quantity to support site cleanup verification decisions within specified error tolerances. The DQA verified that the sample design was sufficient for the purpose of clean site verification. 


\section{B2.0 REFERENCES}

BHI, 2000a, Data Validation Procedure for Chemical Analysis, BHI-01435, Rev. 0, Bechtel Hanford, Inc., Richland, Washington.

BHI, 2000b, Data Validation Procedure for Radiochemical Analysis, BHI-01433, Rev. 0 , Bechtel Hanford, Inc., Richland, Washington.

DOE-RL, 2001, 100 Area Burial Grounds Remedial Action Sampling and Analysis Plan, DOE/RL-2001-35, Rev. 0, U.S. Department of Energy, Richland Operations Office, Richland, Washington.

DOE-RL, 2005, Remedial Design Report/Remedial Action Work Plan for the 100 Area, DOE/RL-96-17, Rev. 5, U.S. Department of Energy, Richland Operations Office, Richland, Washington.

EPA, 1994, USEPA Contract Laboratory Program National Functional Guidelines for Inorganic Data Review, EPA 540/R-94/013, U.S. Environmental Protection Agency, Washington, D.C.

EPA, 2000, Guidance for Data Quality Assessment, EPA QA/G-9, QA00 Update, EPA/600/R-96/084, U.S. Environmental Protection Agency, Office of Environmental Information, Washington, D.C.

WCH, 2006, Remedial Sampling, Logbook EFL-1174-1, Washington Closure Hanford, Richland, Washington. 
CVP-2006-00009

Rev. 0

B-10 
CVP-2006-00009

Rev. 0

APPENDIX C

CALCULATION BRIEF EXCERPTS

C-i 
CVP-2006-00009

Rev. 0

\section{DISCLAIMER FOR CALCULATIONS}

The calculations that are provided in the following appendix have been generated to document compliance with established cleanup levels. These calculations should be used in conjunction with other relevant documents in the administrative record. 


\section{CALCULATION BRIEFS}

The following calculation briefs have been prepared in accordance with ENG-1, Engineering Services, ENG-1-4.5, "Project Calculations," Washington Closure Hanford, Richland, Washington.

100-F-20 Shallow Zone and ACL Stockpile Sampling Plan, Rev. 0, Calculation No. 0100F-CA-V0266, Rev. 0, Washington Closure Hanford, Richland, Washington.

100-F-20 Cleanup Verification 95\% UCL Calculations, Calculation No. 0100F-CA-V0274, Rev. 0, Washington Closure Hanford, Richland, Washington.

NOTE: The calculation briefs referenced in this appendix are kept in the active Washington Closure Hanford project files and are available upon request. When the project is completed, the files will be stored in a U.S. Department of Energy, Richland Operations Office repository. 
CVP-2006-00009

Rev. 0 


\section{CALCULATION COVER SHEET}

Project Title:

Area

Discipline

Subject

Computer Program
100-F-20 PNL Parallel Pits Sample Design 100-F

Environmental Engineering

100-F-20 Shallow Zone and ACL Stockpile Sampling Plan

Excel
Job No.

14655

100F-CA-V0266

Excel 2003

The attached calculations have been generated to document compliance with established cleanup levels. These calculations should be used in conjuction with other relevent documents in the administrative record.

\section{Committed Calculation \\ 凶 \\ Preliminary \\ Superseded \\ Voided}

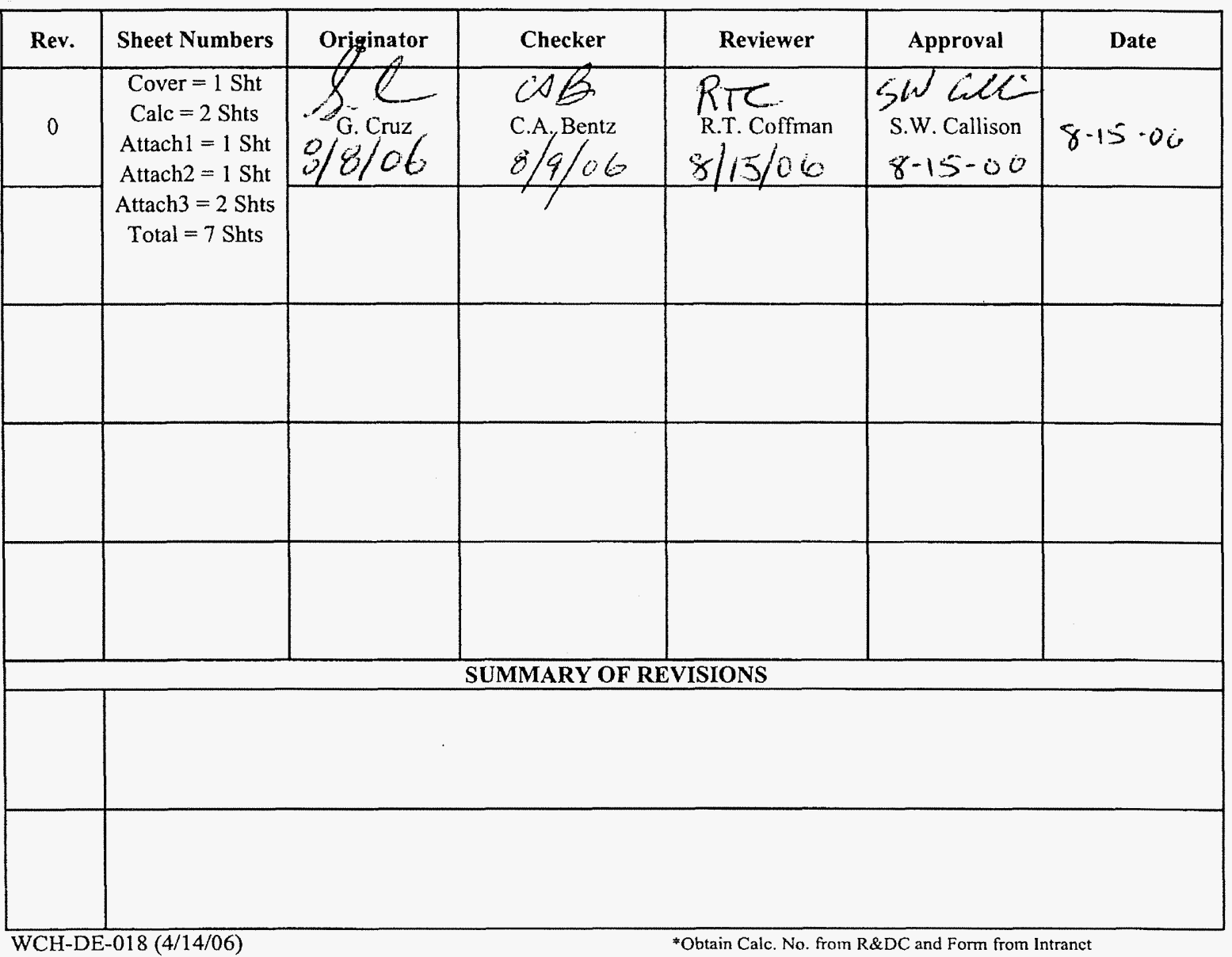


CVP-2006-00009

Rev. 0

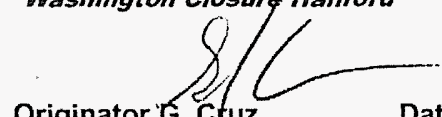

Originator G. Cluz

Project 100-F-20 PNL Parallel Pits Sample Design

Subject
Date $7 / 27 / 2006$ 100-F-20 Shallow Zone and ACL Stockpile Sampling Plan
Calc. No. 0100F-CA-V0266 Rev. No. 0

Job No. 14655 Checked CoB Date

Sheet No. 1 of 2

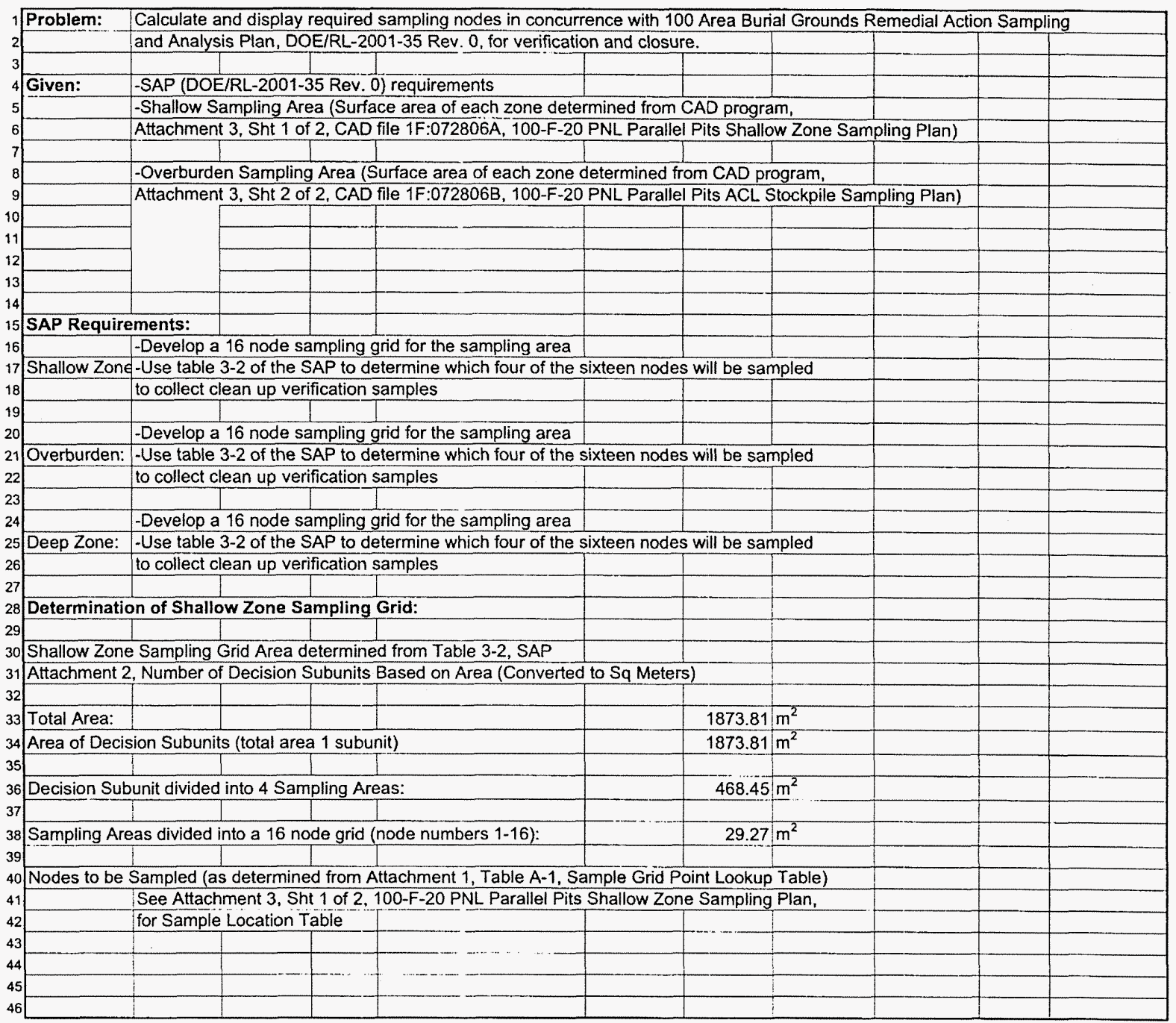




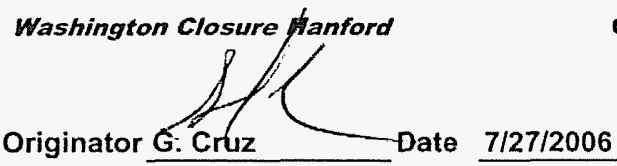

CALCULATION SHEET
Calc. No. 0100F-CA-V0266 Rev. No. 0

Project $\quad 100-F-20$ PNL Parallel Pits Sample Design

Subject 100-F-20 Shallow Zone and ACL Stockpile Sampling Plan
Cof Date $8 / 9 / 06$ Sheet No. 2 of2

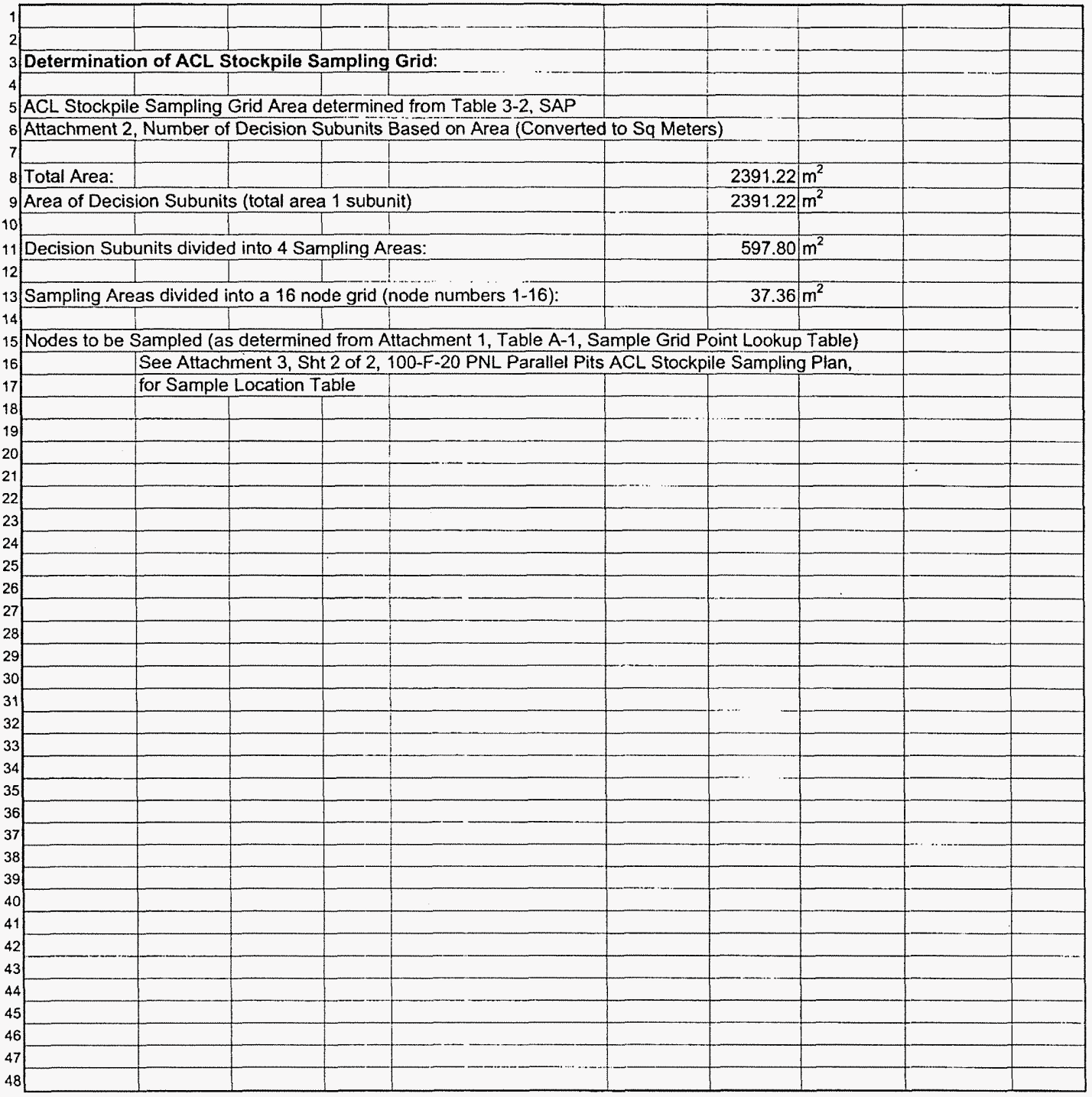


CVP-2006-00009

Rev. 0

Washington Closure Hapford

Originator

Project

Subject<smiles>COC(=O)c1ccc(OC)cc1C</smiles>

Date $\quad 7 / 27 / 2006$ 100-F-20 PNL Parallel Pits Sample Design 100-F-20 Shallow Zone and ACL Stockpile Sampling Plan
Calc. No.0100F-CA-V0266 Rev. No. 0 Job No. 14655 Checked Sheet No 1 of 1

\footnotetext{
4
}

1 ATTACHMENT 1

${ }_{3}$ Sample Grid Point Lookup Table.

\begin{tabular}{|c|c|c|c|c|c|c|c|c|c|c|}
\hline Default Plan & $\begin{array}{c}\text { Sampling } \\
\text { Area } 1\end{array}$ & $\begin{array}{c}\text { Sampling } \\
\text { Area 2 }\end{array}$ & $\begin{array}{c}\text { Sampling } \\
\text { Area } 3\end{array}$ & $\begin{array}{c}\text { Sampling } \\
\text { Area } 4\end{array}$ & $\begin{array}{c}\text { Sampling } \\
\text { Area 5 }\end{array}$ & $\begin{array}{c}\text { Sampling } \\
\text { Area } 6\end{array}$ & $\begin{array}{c}\text { Sampling } \\
\text { Area ? }\end{array}$ & $\begin{array}{c}\text { Sampling } \\
\text { Area } 8\end{array}$ & $\begin{array}{c}\text { Sampling } \\
\text { Area } 9\end{array}$ & $\begin{array}{c}\text { Sampling } \\
\text { Area } 10\end{array}$ \\
\hline Closeout & 3 & 6 & 1 & 4 & 5 & 1 & 3 & 3 & 4 & 16 \\
\hline Closeout & 4 & 7 & 11 & 3 & 15 & 15 & 5 & 13 & 10 & 10 \\
\hline Closeout & 16 & 3 & 2 & 7 & 7 & 10 & 11 & 4 & 3 & 14 \\
\hline Closeout & 10 & 15 & 4 & 12 & 1 & 13 & 4 & 8 & 16 & 4 \\
\hline Not Sampling & 2 & 14 & 5 & 9 & 13 & 12 & 8 & 2 & 14 & 8 \\
\hline Not Sampling & 13 & 10 & 9 & 13 & 2 & 16 & 1 & 12 & 5 & 3 \\
\hline Not Sampling & 6 & 1 & 10 & 8 & 14 & 4 & 16 & 5 & 8 & 6 \\
\hline Not Sampling & 1 & 9 & 13 & 1 & 10 & 5 & 12 & 1 & 1 & 15 \\
\hline Not Sampling & 9 & 12 & 7 & 5 & 6 & 2 & 6 & 7 & 15 & 9 \\
\hline Not Sampling & 15 & 16 & 15 & 14 & 16 & 6 & 2 & 15 & 11 & 1 \\
\hline Not Sampling & 8 & 13 & 8 & 10 & 12 & 11 & 13 & 14 & 2 & 12 \\
\hline Not Sarnpling & 5 & 2 & 3 & 11 & 4 & 3 & 9 & 10 & 7 & 11 \\
\hline Not Sampling & 7 & 11 & 14 & 15 & 11 & 14 & 14 & 6 & 13 & 2 \\
\hline Not Sampling & 11 & 4 & 6 & 2 & 9 & 7 & 7 & 11 & 9 & 7 \\
\hline Not Sampling & 12 & 8 & 16 & 16 & 3 & 8 & 15 & 9 & 6 & 13 \\
\hline Not Sampling & 14 & 5 & 12 & 6 & 8 & 9 & 10 & 16 & 12 & 5 \\
\hline
\end{tabular}

${ }_{24}$ the nodes in the northwesternmost node. Then number consecutively left to right. 
CVP-2006-00009

Rev. 0

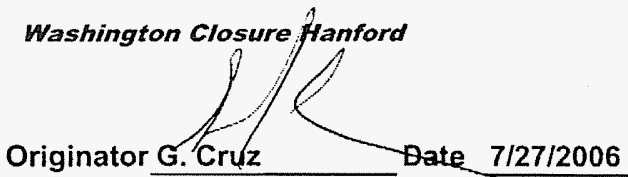

Calc. No. 0100F-CA-V0266

Rev. No. 0

Project 100-F-20 PNL Parallel Pits Sample Design Job No. 14655

Checked

QS Date Sheet No. 1 of 1

Subject 100-F-20 Shallow Zone and ACL Stockpile Sampling Plan

\begin{tabular}{|c|c|c|c|c|c|c|}
\hline \multicolumn{7}{|c|}{${ }_{3}$ Number of Decision Subunits Based on Area. } \\
\hline & \multicolumn{6}{|c|}{ Site Verification Sampling Frequencies Based on Area. } \\
\hline & Decision Unit" & Waste Site Size $^{\text {b }}$ & $\begin{array}{l}\text { Decision } \\
\text { Subunits }\end{array}$ & Blocks & $\begin{array}{l}\text { Discrete } \\
\text { Samples }\end{array}$ & $\begin{array}{c}\text { Composite } \\
\text { Samples }\end{array}$ \\
\hline & \multirow{3}{*}{$\begin{array}{l}\text { Shallow zone - } \\
01015 \mathrm{ft}\end{array}$} & Small: $<100,000 \mathrm{ft}^{2}$ & 1 & 4 & 16 & 4 \\
\hline & & Medium: $>100,000 \mathrm{ft}^{2}<400,000 \mathrm{ft}^{2}$ & 4 & 16 & 64 & 16 \\
\hline & & Large: $>400,000 \mathrm{ft}^{2}$ & 8 & 32 & 128 & 32 \\
\hline & \multirow{3}{*}{$\begin{array}{l}\text { Deep Zone - } \\
>15 \mathrm{ft}\end{array}$} & Small: $<100,000 \mathrm{ft}^{2}$ & $\frac{1}{1}$ & 4 & 16 & 4 \\
\hline & & Medium: $>100,000 \mathrm{ft}^{2}<400,000 \mathrm{ft}^{2}$ & 4 & 16 & 64 & 16 \\
\hline & & Large: $>400,000 \mathrm{ft}^{2}$ & 8 & 32 & 128 & 32 \\
\hline & \multirow{3}{*}{$\begin{array}{l}\text { Overburen/layback } \\
\text { stockpiles }\end{array}$} & Small: $<100,000 \mathrm{ft}^{2}$ & 1 & 4 & 16 & 4 \\
\hline & & Medium: $>100,000 \mathrm{ft}^{2}<400,000 \mathrm{ft}^{2}$ & 4 & 16 & 64 & 16 \\
\hline & & Large: $>400,000 \mathrm{ft}^{2}$ & 8 & 32 & 128 & 32 \\
\hline & \multirow{3}{*}{$\begin{array}{l}\text { Staging pile areas } \\
\text { (residual soil) }\end{array}$} & Small: $<100.000 \mathrm{ft}^{2}$ & 1 & 4 & 16 & 4 \\
\hline & & Medium: $>100,000 \mathrm{ft}^{2}<400,000 \mathrm{ft}^{2}$ & 4 & 16 & 64 & 16 \\
\hline & & Large: $>400,000 \mathrm{ft}^{2}$ & 8 & 32 & 128 & 32 \\
\hline
\end{tabular}

- The shallow zone, decp zone, ovcrburden stockpilc, and staging pile arcas each represent single decision units. The total number of decision units will vary because individual waste sites may not have a deep zone, overburden stockpile, and/or staging pilc arcas.

- Area of exposed surface after excavation or arca of stockpilc basc (as applicable)

- Decision subunits are divided into four blocks to ensure that random sampling locations are not bunched together in one area 
CVP-2006-00009

Rev. 0

C-6 


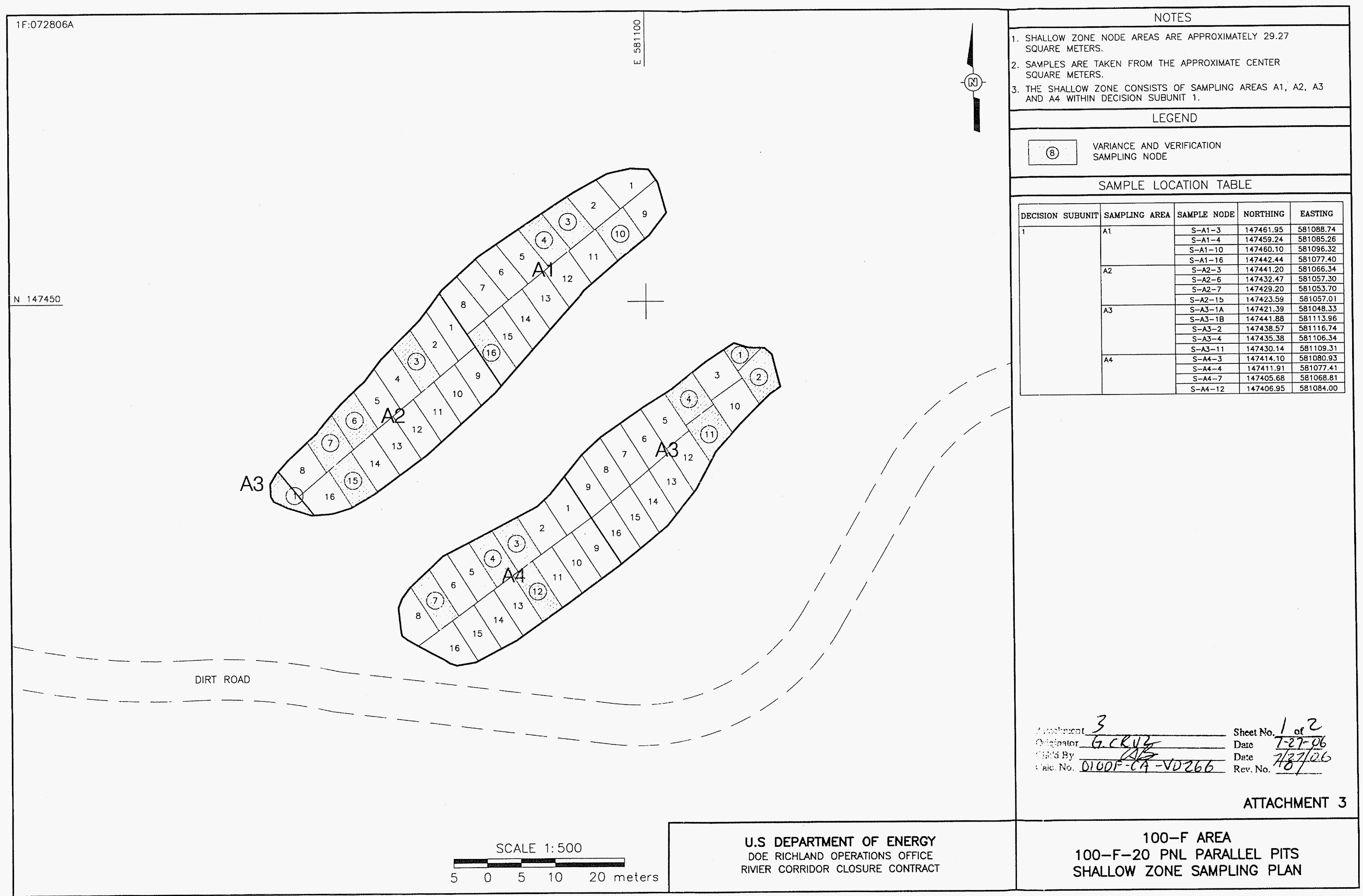




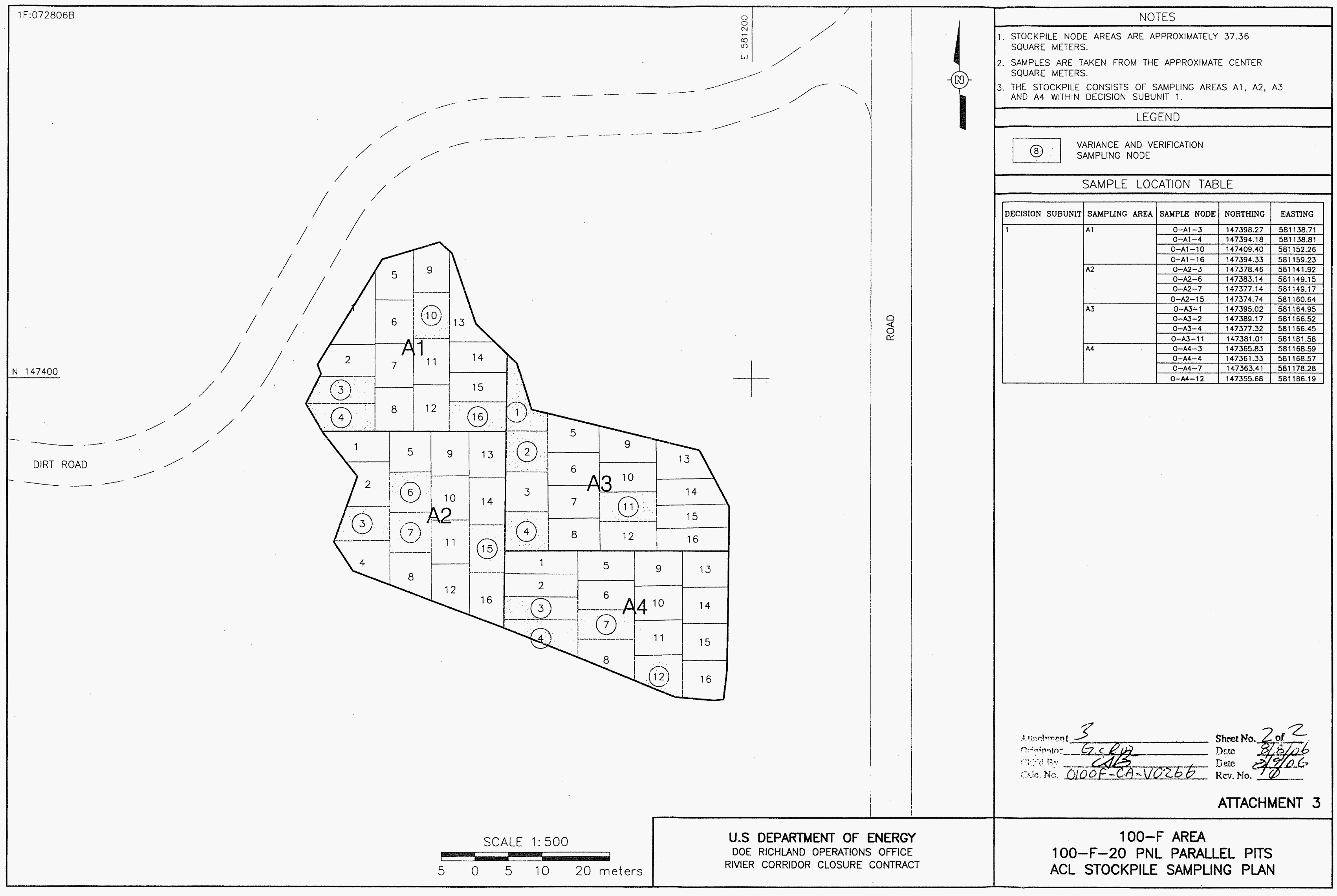


CVP-2006-00009

Rev. 0

\section{CALCULATION COVER SHEET}

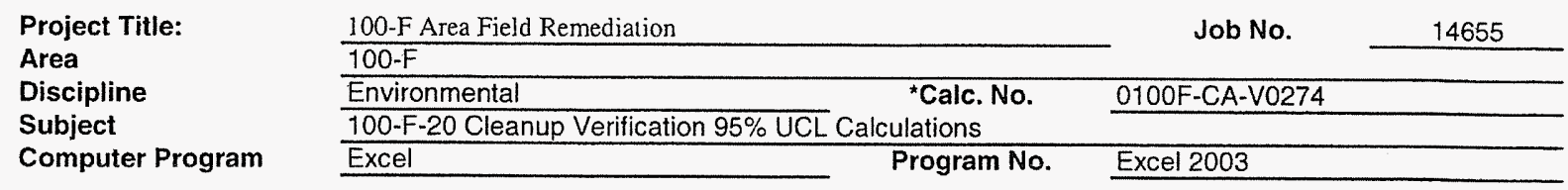

The attached calculations have been generated to document compliance with established cleanup levels. These calculations should be used in conjunction with other relevant documents in the administrative record.

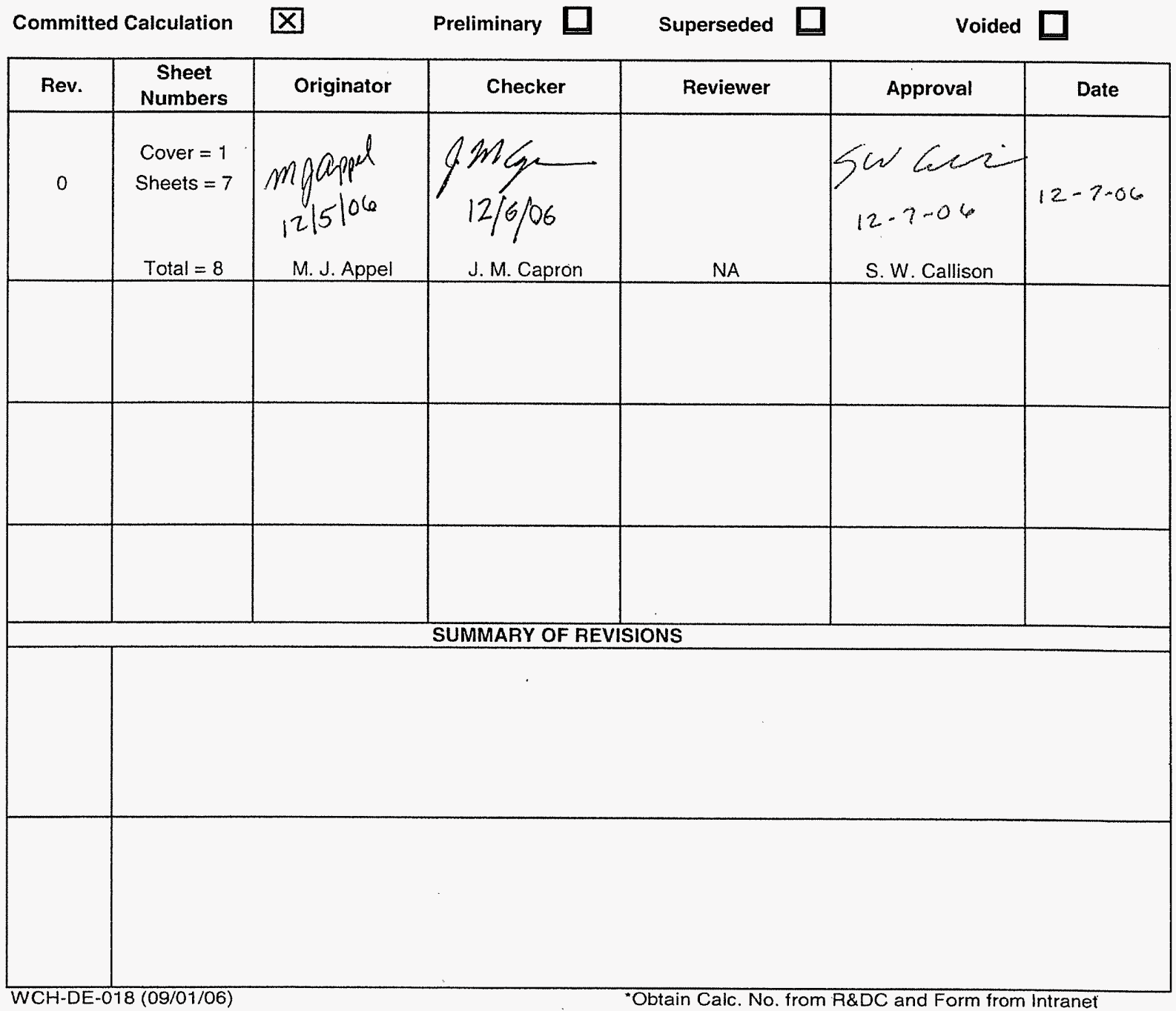


2 Calculate the $95 \%$ upper confidence limit (UCL) to evaluate compliance with cleanup standards for the subject site. Also, calculate the carcinogenic risk for applicable nonradionuclide analytes, perform the Washington Administrative Code (WAC) 173-340 (Model Toxics Control Act-Cleanup) 3-part test, if required, and calculate the relative percent difference (RPD) for each contaminant of concern (COC).

2) Background values and remedial action goals (RAGs) are taken from DOE-RL (2005b), DOE-RL (2001), and Ecology (2005).

3) DOE-RL, 2001a, 100 Area Burial Grounds Remedial Action Sampling and Analysis Plan, DOE/RL 2001-35, Rev. 0, U.S. Department of Energy, Richland Operations Office, Richland, Washington.

4) DOE-RL, 2001b, Hanford Site Background: Part 1, Soil Background for Nonradioactive Analytes, DOE/RL-92-24, Rev. 4, U.S. Department of Energy, Richland Operations Office, Richland, Washington.

5) DOE-RL, 2005, Remedial Design Report/Remedial Action Work Plan for the 100 Area (RDR/RAWP), DOE/RL-96-17, Rev. 5, U.S. Department of Energy, Richland Operations Office, Richland, Washington.

6) Ecology, 1992, Statistical Guidance for Ecology Site Managers, Publication \#92-54, Washington Department of Ecology, Olympia, Washington.

7) Ecology, 1993, Statistical Guidance for Ecology Site Managers, Supplement S-6, Analyzing Site or Background Data with Below-detection Limit or Below-PQL Values (Censored Data Sets), Publication \#92-54, Washington Department of Ecology, Olympia, Washington.

8) Ecology, 2005, Cleanup Levels and Risk Calculations (CLARC) Database, Washington State Department of Ecology, Olympia, Washington, <https://fortress.wa.gov/ecy/clarc/CLARCHome.aspx>.

9) EPA, 1994, USEPA Contract Laboratory Program National Functional Guidelines for Inorganic Data Review, EPA 540/R-94/013. U.S. Environmental Protection Agency, Washington, D.C.

10) WAC 173-340, 1996, "Model Toxic Control Act - Cleanup," Washington Administrative Code.

Solution:

Calculation methodology is described in Ecology Pub. \#92-54 (Ecology 1992, 1993), below, and in the BDR/RAWP (DOE-RL 2005). Use data from the attached worksheets to calculate the $95 \%$ UCL, hazard quotients, excess carcinogenic risk, perform the WAC 173-340 3-part test for nonradionuclides, and calculate the RPD for each COC in the primary-duplicate and primary-split sample pairs. 47 Calculation Description:

48 The subject calculations were performed on data from soil verification samples from the 100-F-20 waste site. The data were entered into an EXCEL 492003 spreadsheet and calculations performed by utilizing the built-in spreadsheet functions and/or creating formulae within the cells. The statistical 51 evaluation of data for use in accordance with the RDR/RAWP (DOE-RL 2005) is documented by this calculation. Split and duplicate RPD results are 52 used in evaluation of data quality and are presented in the cleanup verification package (CVP) for this site.

54 Methodology:

55 For nonradioactive analytes with $<50 \%$ of the data below detection limits and all radionuclide analytes, the statistical value calculated to evaluate the 57 effectiveness of cleanup is the $95 \%$ UCL. For nonradioactive analytes with $>50 \%$ of the data below detection limits, the maximum value for the data set 58 is used instead of the $95 \%$ UCL. All nonradionuclide data reported as being below detection limits are set to $1 / 2$ the detection limit value for calculation 59 of the statistics (Ecology 1993). For radionuclide data, calculation of the statistics was done on the reported value. In cases where the laboratory does 60 not report a value below the minimal detectable activity (MDA), half of the MDA is used in the calculation. For the statistical evaluation of primary62 duplicate sample pairs, the samples are averaged before being included in the data set, after adjustments for censored data as described above. 
Washington Closure Hanford

Originator M. J.Appel $M A A$

Project 100 -F Area Field Remediation

Subject $100-\mathrm{F}-20$ Cleanup Verification $95 \%$ UCL Calculations
CALCULATION SHEET

Date 12/05/08

Job No. 14655
Calc. No. 0100F-CA-V0274

Checked J.M. Capron Y $<$

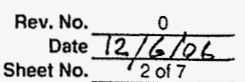

Summary (continued)

Methodology (continued)

The COCs for the 100-F-20, PNL Parallel Pits are: lead, cobalt-60, cesium-137, nickel-63, strontium-90, and Plutonium-239/240. All other sampling results for the non-COC metal analyses were within the range of natural Hanford background levels (DOE-PL 2001b) and, therefore, not evaluated.

For nonradionuclides, the WAC 173-340 statistical guidance suggests that a test for distributional form be performed on the data and the $95 \%$ UCL calculated on the appropriate distribution using Ecology software. For nonradionuclide small data sets $(n<10)$ and all radionuclide data sets, the calculations are pertormed assuming nonparametric distribution, so no test for distribution is performed. For nonradionuclide data sets of ten or greater, distributional testing is done using Ecology's MTCAStat software (Ecology 1993). Background values are subtracted for applicable radionuclides only. Comparison against background levels for nonradionuclides is included within the CVP.

The hazard quotient (for shallow zone nonradionuclide COCs) is determined by dividing the statistical value (derived in this calculation) by the WAC 173-340 non-carcinogenic cleanup limit. The excess nonradionuclide carcinogenic risk is determined by dividing the statistical value by the WAC 173-340 carcinogenic cleanup limit and then multiplying by $10^{-6}$. Calculation of the hazard quotient was not required for $100-\mathrm{F}-20$ because the only noradionuclide COC was lead. Lead does not have a reference dose (RfD) for use in the hazard quotient calculation because the toxic effects of lead are correlated with blood-lead levels rather than exposure levels or daily intake (EPA 1994). Calculation of the nonradionuclide carcinogenic risk was not calculated because lead does not have an associated carcinogenic risk.

The WAC 173-340 3-part test is performed for nonradionuclide analytes only and determines if:

1) the $95 \%$ UCL value exceeds the most stringent cleanup limit for each non-radionuclide $\mathrm{COC}$,

2) greater than $10 \%$ of the raw data exceed the most stringent cleanup limit for each non-radionuclide COC

3) the maximum value of the raw data set exceeds two times the most stringent cleanup limit for each non-radionuclide COC

The RPD values are evaluated for analytes detected in a primary-duplicate or primary-split sample pair for the purposes of data quality assessment within the CVP. The RPD is calculated when both the primary value and either the duplicate or split values are above detection limits and are greater than 5 times the target detection limit (TDL). The TDL is a laboratory detection limit pre-determined for each analytical method, listed in Table II-1 of the SAP (DOE-RL 2001a). The RPD calculations use the following formula: $R P D=[|M-S| /(M+S) / 2)]^{*} 100$

where, $\quad M=$ Main Sample Value

S = Split (or duplicate) Sample Value

For quality assurance/quality control (QA/QC) split and duplicate RPD calculations, a value less than $+/-30 \%$ indicates the data compare favorably. For regulatory splits, a threshold of $35 \%$ is used (EPA 1994). If the RPD is greater than $30 \%$ (or $35 \%$ for regulatory split data), further investigation regarding the usability of the data is performed. Additional discussion as necessary is provided in the data quality assessment section of the applicable CVP.

If regulator split comparison is required, an additional parameter is evaluated. A control limit of $+/-2$ times the TDL shall be used if either the main or regulator split value is less than 5 times the TDL and above detection. In the case where only one result is greater than 5 times the TDL and the other is below, the $+/-2$ times the TDL criteria applies. Thereiore, the following calculation is performed as part of the evaluation for these two cases involving regulator split data: difference = main - regulator split. If the difference is greater than $+/-2$ times the TDL, then further investigation regarding the usability of the data is performed and presented in the applicable CVP data quality assessment section.

No regulatory split samples were collected for this site. 
CVP-2006-00009

Rev. 0

Washington Closure Hanford

Originator M.J.Appel in

Project $100-\mathrm{F}$ Area Field Remediation

Subject $100-\mathrm{F}-20$ Cleanup Verification $95 \%$ UCL Calculations

CALCULATION SHEET

ontinued)

1 Results:

2 The results presented in the summary tables that follow are for use in the 100-F-20 CVP.

3

\begin{tabular}{|c|c|c|c|c|c|c|}
\hline \multirow{3}{*}{$\begin{array}{l}5 \\
6\end{array}$} & \multicolumn{6}{|c|}{ Results Surmmary } \\
\hline & \multirow{2}{*}{ Analyte } & \multicolumn{2}{|c|}{ Shallow Zone } & \multicolumn{2}{|c|}{ Waste Staging Plle Footprint } & \multirow{2}{*}{ Units } \\
\hline & & Pesult & Qualifier & Result & Qualifier & \\
\hline & Lead & 24.1 & & 18.0 & & $\mathrm{mg} / \mathrm{kg}$ \\
\hline & Cesium-137 & 0.024 & $\mathrm{U}$ & 0.052 & & pCivg \\
\hline & Cobalt -60 & 0.053 & $\mathrm{U}$ & 0.140 & $\bar{U}$ & $\mathrm{pCl} / \mathrm{g}$ \\
\hline 0 & Nickel-63 & -0.192 & $\bar{U}$ & 1.91 & & pCivg \\
\hline & Plutonium-239/240 & 0.025 & U & 0.057 & $U$ & $\mathrm{pCi} / \mathrm{g}$ \\
\hline 12 & Strontium-90 & 0.075 & $\bar{U}$ & 0.141 & & pCigg \\
\hline
\end{tabular}

2 Strontium-90

$13 \mathrm{U}=$ undetected

14
15

16 WAC 173-340 Evaluation (Shallow Zone)

WAC 173-340 Evaluation (Waste Staging Pile Footprint)

18 3.Part Tes:

$995 \%$ UCL $>$ Cleanup Limit? YES

$\begin{array}{ll}20>10 \% \text { above Cleanup Limit? } & \text { YES } \\ 21 \text { Any sample }>2 x \text { Cleanup Limit? } & \text { YES }\end{array}$

22

23 Because of the "yes" answers to the WAC 173-340, additional

24 site-specific evaluation will be performed for lead within the CVP.

26

28 Relative Percent Difference Results" ONOC Analysis

\begin{tabular}{|c|c|c|c|c|c|}
\hline \multirow[t]{2}{*}{29} & \multirow[b]{2}{*}{ Analyte } & \multicolumn{2}{|c|}{ Shallow Zone } & \multicolumn{2}{|c|}{ Waste Staging Area } \\
\hline & & $\begin{array}{l}\text { Duplicate } \\
\text { Anaiysis** }\end{array}$ & $\begin{array}{c}\text { Split } \\
\text { Analysis** }\end{array}$ & $\begin{array}{l}\text { Duplicate } \\
\text { Analysis"* }\end{array}$ & $\begin{array}{c}\text { Split } \\
\text { Analysis** }\end{array}$ \\
\hline 31 & Aluminum & NA & NA & $4.6 \%$ & $18.8 \%$ \\
\hline 32 & Antimony & NA & NA & & \\
\hline 33 & Arsenic & NA & NA & & \\
\hline 34 & Barium & NA & NA & $6.8 \%$ & $9.9 \%$ \\
\hline 35 & Beryllium & $\mathrm{NA}$ & $\mathrm{NA}$ & & \\
\hline 36 & Boron & NA & NA & & \\
\hline 37 & Cakcium & NA & NA & $6.3 \%$ & $12.4 \%$ \\
\hline 38 & Total Chromium & $\mathrm{NA}$ & NA & $8.0 \%$ & $76.6 \%$ \\
\hline 39 & Cobalt & $\mathrm{NA}$ & $\mathrm{NA}$ & & \\
\hline 40 & Copper & NA & NA & $4.4 \%$ & $12.3 \%$ \\
\hline 41 & Iron & $\mathrm{NA}$ & NA & $7.7 \%$ & $4.0 \%$ \\
\hline 42 & Lead & & & & \\
\hline 43 & Magnesium & $\mathrm{NA}$ & NA & $0.6 \%$ & $13.9 \%$ \\
\hline 44 & Manganese & $\mathrm{NA}$ & NA & $1.1 \%$ & $2.1 \%$ \\
\hline 45 & Mercury & $\mathrm{NA}$ & $\mathrm{NA}$ & & \\
\hline 46 & Molivbdenum & NA & NA & & \\
\hline 47 & Nickel & NA & NA & $4.4 \%$ & $12.3 \%$ \\
\hline 48 & Potassium & $\mathrm{NA}$ & NA & & \\
\hline 49 & Silicon & NA & NA & $0.2 \%$ & $43.3 \%$ \\
\hline 50 & \begin{tabular}{|l} 
Sodium \\
\end{tabular} & NA & NA & & \\
\hline 51 & \begin{tabular}{|l|} 
Vanadium \\
\end{tabular} & NA & NA & $3.6 \%$ & $4.2 \%$ \\
\hline 52 & Zinc & NA & NA & $0.9 \%$ & $7.8 \%$ \\
\hline 53. & Cesium-137 & & & & \\
\hline 54 & Cobalt-60 & & & & \\
\hline 55 & Nickel-63 & & & & \\
\hline 56 & Potassium-40 & $66.7 \%$ & & & \\
\hline 57 & Plutonium-239/240 & & & & \\
\hline 58 & $\begin{array}{l}\text { Fadium-226 } \\
\end{array}$ & $54.5 \%$ & & & \\
\hline $59^{\prime}$ & Radium-228 & & & & \\
\hline 60 & Strontium-90 & & & & \\
\hline 61 & Thorium-228 & & & & \\
\hline 62. & Thorium-232 & & & & \\
\hline
\end{tabular}

1 Thorium-228

.-The signilicance of the reported APD values, including values greater than $30 \%$, is addressed within the Data Quallty Assessment section of the CVP tor this sitte.

$65 \mathrm{NA}=$ not applicable-enalysis not pertormed.

66 OAOC = quaitity assurance/quality controd

$67 \mathrm{APD}=$ relative percent diflerence

3-Pant Tes:

$95 \%$ UCL $>$ Cleanup Limil? YES

$>10 \%$ above Cleanup Limit?
Any sample $>2 \times$ Cleanup Limit? NO

Because of the 'yes' answers to the WAC

173-340, additional site-specific evaluation will be

periormed for lead within the CVP. 
Originator M. J. Appel $M / p t$ Project $100-\mathrm{F}$ Area Field Remediation Subject $100-F-20$ Cleanup Verification $95 \%$ UCL Calculations
Date 12/5/06

Job No. 14655
CALCULATION SHEET

\begin{tabular}{|c|c|c|c|c|c|c|c|c|c|c|c|c|c|c|c|c|c|c|c|c|}
\hline \multirow{2}{*}{$\begin{array}{c}\text { Sampling } \\
\text { Area }\end{array}$} & \multirow{2}{*}{$\begin{array}{l}\text { Sample } \\
\text { Number }\end{array}$} & \multirow{2}{*}{$\begin{array}{c}\text { Sample } \\
\text { Date }\end{array}$} & \multicolumn{3}{|c|}{ Lead } & \multicolumn{3}{|c|}{ Cesium-137 } & \multicolumn{3}{|c|}{ Cobalt-60 } & \multicolumn{3}{|c|}{ Nickel-63 } & \multicolumn{3}{|c|}{ Plutonium-239/240 } & \multicolumn{3}{|c|}{ Strontium-90 } \\
\hline & & & $\mathrm{mg} / \mathrm{kg}$ & $\mathbf{Q}$ & PQL & $\mathrm{pCi} / \mathrm{g}$ & $Q$ & MDA & $\mathrm{pCi} / \mathrm{g}$ & Q & MDA & $\mathrm{pCi} / \mathrm{g}$ & \begin{tabular}{|l|l}
$\mathbf{Q}$ & \\
\end{tabular} & MDA & $\mathrm{pCi} / \mathrm{g}$ & $\mathbf{Q}$ & MDA & $\mathrm{pCi} / \mathrm{g}$ & Q & $\overline{M D A}$ \\
\hline A1 & J135B2 & $8 / 16 / 06$ & 10.9 & & 0.3 & 0.051 & $u$ & 0.051 & 0.053 & $u$ & 0.053 & -0.496 & $u$ & 3.4 & 0.047 & $u$ & 0.089 & 0.065 & $u$. & 0.22 \\
\hline A2 & J135B4 & $8 / 16 / 06$ & 3.8 & & 0.3 & 0.019 & $\mathrm{u}$ & 0.019 & 0.019 & $u$ & 0.019 & -1.43 & $u$ & 3.4 & 0.020 & $\mathrm{u}$ & 0.064 & 0.012 & u & 0.27 \\
\hline A4 & J135B6 & $8 / 16 / 06$ & 31.2 & & 0.31 & 0.032 & $u$ & 0.032 & 0.031 & $u$ & 0.031 & -1.17 & $u$ & 3.4 & 0.007 & $u$ & 0.051 & 0.071 & $u$ & 0.22 \\
\hline $\begin{array}{c}\text { Duplicate of } \\
\mathrm{J} 135 \mathrm{~B} 2\end{array}$ & J135B3 & $8 / 16 / 06$ & 11.9 & & 0.3 & 0.042 & $u$ & 0.042 & 0.041 & u & 0.041 & 0.429 & $u$ & 3.6 & 0.011 & $u$ & 0.042 & 0.030 & $u$ & 0.23 \\
\hline
\end{tabular}$$
\begin{array}{r}
9 \\
10
\end{array}
$$

11 Statistical Computation Input Data

\begin{tabular}{|c|c|c|c|c|}
\hline & $\begin{array}{c}\text { Sampling } \\
\text { Area }\end{array}$ & $\begin{array}{c}\text { Sample } \\
\text { Number } \\
\end{array}$ & $\begin{array}{c}\text { Sample } \\
\text { Date }\end{array}$ & \begin{tabular}{|c} 
Lead \\
$\mathrm{mg} / \mathrm{kg}$
\end{tabular} \\
\hline 14 & $\mathrm{~A} 1$ & $\mathrm{~J} 135 \mathrm{~B} 2 / \mathrm{J} 135 \mathrm{~B} 3$ & $8 / 16 / 2006$ & 11.4 \\
\hline 15 & A2 & J135B4 & $8 / 16 / 2006$ & 3.8 \\
\hline 16 & $A 3$ & J135B5 & $8 / 16 / 2006$ & 11.4 \\
\hline 17 & A4 & $\mathrm{J} 135 \mathrm{~B} 6$ & $8 / 16 / 2006$ & 31.2 \\
\hline
\end{tabular}

\begin{tabular}{|c|c|}
\hline \multirow{2}{*}{\multicolumn{2}{|c|}{$\begin{array}{c}\text { Cesium-137 } \\
\text { pCi/g }\end{array}$}} \\
\hline & \\
\hline $\begin{array}{l}0.010 \\
0.024\end{array}$ & \\
\hline
\end{tabular}

\begin{tabular}{|c|l|l|}
\hline $\begin{array}{c}\text { Cobalt-60 } \\
\text { pCi/g }\end{array}$ & \multicolumn{2}{l}{} \\
\hline 0.024 & & \\
\hline 0.010 & & \\
\hline 0.023 & & \\
\hline 0.016 & &
\end{tabular}

\begin{tabular}{|c|c|}
\hline $\begin{array}{r}\text { Nickel-63 } \\
\text { pCi/g }\end{array}$ & \\
\hline-0.034 & \\
\hline-1.43 & \\
\hline-0.326 & \\
\hline
\end{tabular}

\begin{tabular}{|l|l|l|l|l|}
\hline $\begin{array}{l}\text { Plutonium-239/240 } \\
\text { pCi/g }\end{array}$ & \multicolumn{2}{|l|}{$\begin{array}{l}\text { Strontium-90 } \\
\text { pCi/g }\end{array}$} \\
\hline 0.029 & & 0.048 & & \\
\hline 0.020 & & 0.012 & & \\
\hline-0.004 & & 0.074 & & \\
\hline 0.007 & & 0.071 & & \\
\hline
\end{tabular}

20 Statistical Computations

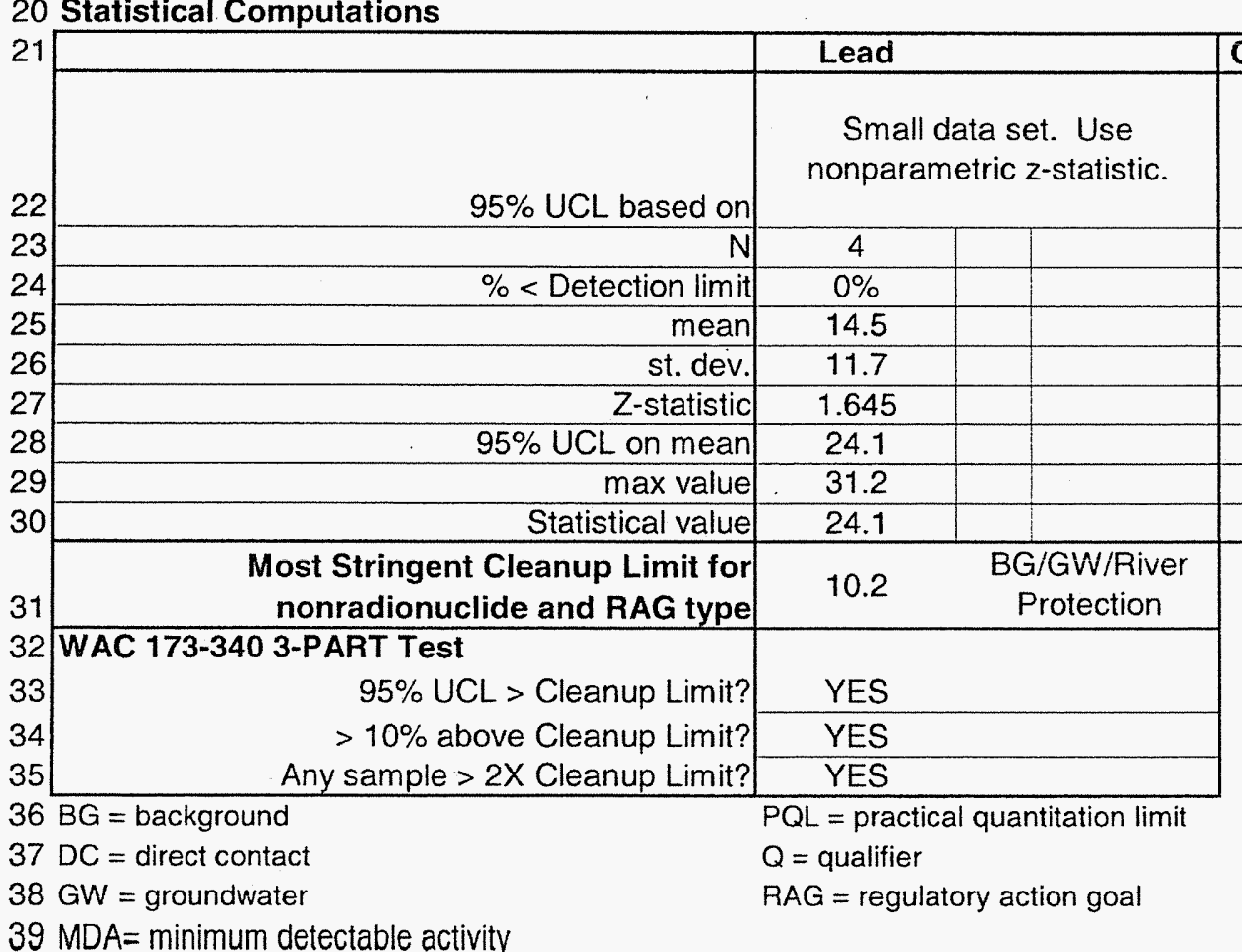

\begin{tabular}{|c|c|c|c|c|c|c|c|c|c|c|c|c|c|c|}
\hline \multirow{2}{*}{\multicolumn{3}{|c|}{$\begin{array}{l}\text { Cesium-137 } \\
\text { Radionuclide data set. Use } \\
\text { nonparametric z-statistic. }\end{array}$}} & \multirow{2}{*}{\multicolumn{3}{|c|}{$\begin{array}{l}\text { Cobalt-60 } \\
\text { Radionuclide data set. Use } \\
\text { nonparametric z-statistic. }\end{array}$}} & \multirow{2}{*}{\multicolumn{3}{|c|}{$\begin{array}{c}\text { Nickel-63 } \\
\begin{array}{l}\text { Radionuclide data set. Use } \\
\text { nonparametric z-statistic. }\end{array}\end{array}$}} & \multirow{2}{*}{\multicolumn{3}{|c|}{\begin{tabular}{|l} 
Plutonium-239/240 \\
Radionuclide data set. Use \\
nonparametric z-statistic.
\end{tabular}}} & \multirow{2}{*}{\multicolumn{3}{|c|}{\begin{tabular}{|c|} 
Strontium-90 \\
Radionuclide data set. \\
Use nonparametric z- \\
statistic.
\end{tabular}}} \\
\hline & & & & & & & & & & & & & & \\
\hline 4 & & & 4 & & & 4 & & & 4 & & & 4 & & \\
\hline $100 \%$ & & & $100 \%$ & & & $100 \%$ & & & $100 \%$ & & & $100 \%$ & & \\
\hline 0.018 & & & 0.018 & & & $\begin{array}{r}-0.740 \\
\end{array}$ & & & 0.013 & & & 0.051 & & \\
\hline 0.007 & & & 0.007 & & & 0.666 & & & 0.014 & & & 0.029 & & \\
\hline 1.645 & & & 1.645 & & & 1.645 & & & 1.645 & & & 1.645 & & \\
\hline 0.024 & & & 0.023 & & & -0.192 & & & 0.025 & & & 0.075 & & \\
\hline 0.051 & U & & 0.053 & $U$ & & 0.429 & $U$ & & 0.047 & $U$ & & 0.074 & $U$ & \\
\hline 0.024 & U & & 0.053 & $U$ & & -0.192 & $U$ & & 0.025 & $U$ & & $0: 075$ & U & \\
\hline
\end{tabular}

$U=$ undetected

$39 \mathrm{MDA}=$ minimum detectable activity
WAC = Washington Administrative Code

$Q=$ qualifier $\mathrm{RAG}=$ regulatory action goal 
Originator M. J. Appel $M Y A$

Subject $100-\mathrm{F}-20$ Cleanup Verification $95 \%$ UCL Calculations

$$
\text { Date } \frac{12 / 5 / 06}{14655}
$$

Calc. No. 0100F-CA-V0274

Checked J.M. Capron Ylenc

\begin{tabular}{|c|c|c|c|c|c|c|c|c|c|c|c|c|c|c|c|c|c|c|c|c|}
\hline \multirow{3}{*}{\begin{tabular}{|l|l|} 
& $\begin{array}{c}\text { Sampling } \\
\text { Area }\end{array}$ \\
\end{tabular}} & \multirow{3}{*}{$\begin{array}{l}\text { Sample } \\
\text { Number }\end{array}$} & \multirow{3}{*}{$\begin{array}{c}\text { Imple Data } \\
\text { Sample } \\
\text { Date }\end{array}$} & \multirow{2}{*}{\multicolumn{3}{|c|}{ Lead }} & \multirow{2}{*}{\multicolumn{3}{|c|}{ Cesium-137 }} & \multirow{2}{*}{\multicolumn{3}{|c|}{ Cobalt-60 }} & \multirow{2}{*}{\multicolumn{3}{|c|}{ Nickel-63 }} & \multirow{2}{*}{\multicolumn{3}{|c|}{ Plutonium-239/240 }} & \multirow{2}{*}{\multicolumn{3}{|c|}{ Strontium-90 }} \\
\hline & & & & & & & & & & & & & & & & & & & & \\
\hline & & & $\mathrm{mg} / \mathrm{kg}$ & Q & $P Q L$ & $\mathrm{pCi} / \mathrm{g}$ & $Q$ & MDA & $\mathrm{pCi} / \mathrm{g}$ & $Q$ & MDA & $\mathrm{pCi} / \mathrm{g}$ & \begin{tabular}{l|l}
$\mathbf{Q}$ \\
\end{tabular} & MDA & $\mathrm{pCi} / \mathrm{g}$ & Q. & MDA & $\mathrm{pCi} / \mathrm{g}$ & Q & MDA \\
\hline $4 \quad \mathrm{~A} 1$ & J135W1 & $8 / 31 / 06$ & 17.7 & & 0.36 & 0.032 & $U$ & 0.032 & 0.036 & $u$ & 0.036 & 0.814 & $u$ & 3.30 & 0.00 & $U$ & 0.380 & -0.042 & $\mathrm{U}$ & 0.220 \\
\hline $\mathrm{A} 2$ & J135W2 & $8 / 31 / 06$ & 8.4 & & 0.35 & 0.046 & $u$ & 0.046 & 0.041 & $u$ & 0.041 & 0.085 & $u$ & 3.50 & 0.00 & $u$ & 0.240 & 0.159 & $\mathrm{u}$ & 0.250 \\
\hline $\mathrm{A} 3$ & J135W4 & $8 / 31 / 06$ & 3.5 & & 0.37 & 0.120 & $U$ & 0.120 & 0.140 & $u$ & 0.140 & 1.04 & $U$ & 3.50 & 0.00 & $u$ & 0.240 & -0.045 & $u$ & 0.230 \\
\hline $\begin{array}{l}\text { Duplicate of } \\
\text { J135W2 }\end{array}$ & J135W3 & $8 / 31 / 06$ & 7.6 & & 0.35 & 0.042 & $u$ & 0.042 & 0.046 & $u$ & 0.046 & 4.68 & & 3.70 & 0.172 & $u$ & 0.260 & 0.265 & & 0.230 \\
\hline
\end{tabular}

Rev. No. $\frac{0}{12 / 6 / 00}$ 9

11 Statistical Computation Input Data

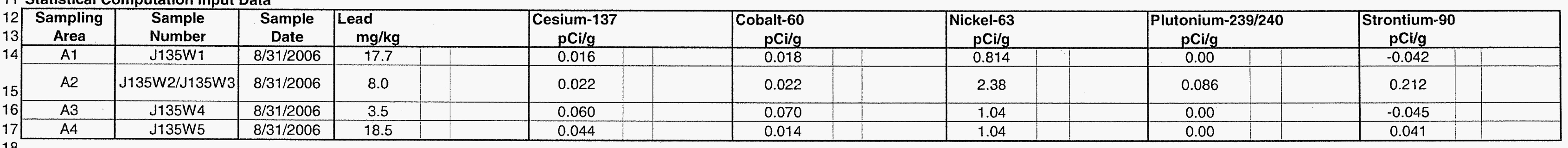

20 Statistical Computations

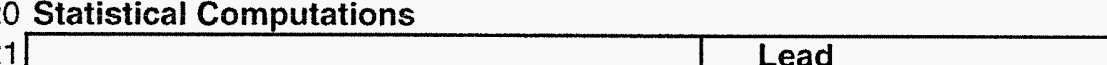

\begin{tabular}{|c|c|c|c|c|c|c|c|c|c|c|c|}
\hline \multirow{2}{*}{\multicolumn{2}{|c|}{$\begin{array}{l}\text { Cesium-137 } \\
\text { Radionuclide data set. Use } \\
\text { nonparametric z-statistic. }\end{array}$}} & \multicolumn{3}{|c|}{ Cobalt-60 } & \multicolumn{2}{|c|}{ Nickel-63 } & \multicolumn{3}{|c|}{ Plutonium-239/240 } & \multicolumn{2}{|c|}{ Strontium-90 } \\
\hline & & \multicolumn{3}{|c|}{$\begin{array}{l}\text { Radionuclide data set. Use } \\
\text { nonparametric } z \text {-statistic. }\end{array}$} & \multicolumn{2}{|c|}{$\begin{array}{l}\text { Radionuclide data set. Use } \\
\text { nonparametric z-statistic. }\end{array}$} & \multicolumn{3}{|c|}{$\begin{array}{l}\text { Radionuclide data set. Use } \\
\text { nonparametric } z \text {-statistic. }\end{array}$} & \multicolumn{2}{|c|}{$\begin{array}{l}\text { Radionuclide data set. Us } \\
\text { nonparametric } z \text {-statistic. }\end{array}$} \\
\hline 4 & & 4 & & & 4 & & 4 & & & 4 & \\
\hline $75 \%$ & & $100 \%$ & & & $75 \%$ & & $100 \%$ & & & $75 \%$ & \\
\hline 0.036 & & 0.031 & & & 1.32 & & 0.022 & & & 0.042 & \\
\hline 0.020 & & 0.026 & & & 0.717 & & 0.043 & & & 0.120 & \\
\hline 1.645 & & 1.645 & & & 1.645 & & 1.645 & & & 1.645 & \\
\hline 0.052 & & 0.053 & & & 1.91 & & 0.057 & & & 0.141 & \\
\hline 0.120 & & 0.140 & $U$ & & 4.68 & & 0.172 & $U$ & & 0.265 & \\
\hline 0.052 & & 0.140 & & & 1.91 & & 0.057 & & & 0.141 & \\
\hline
\end{tabular}

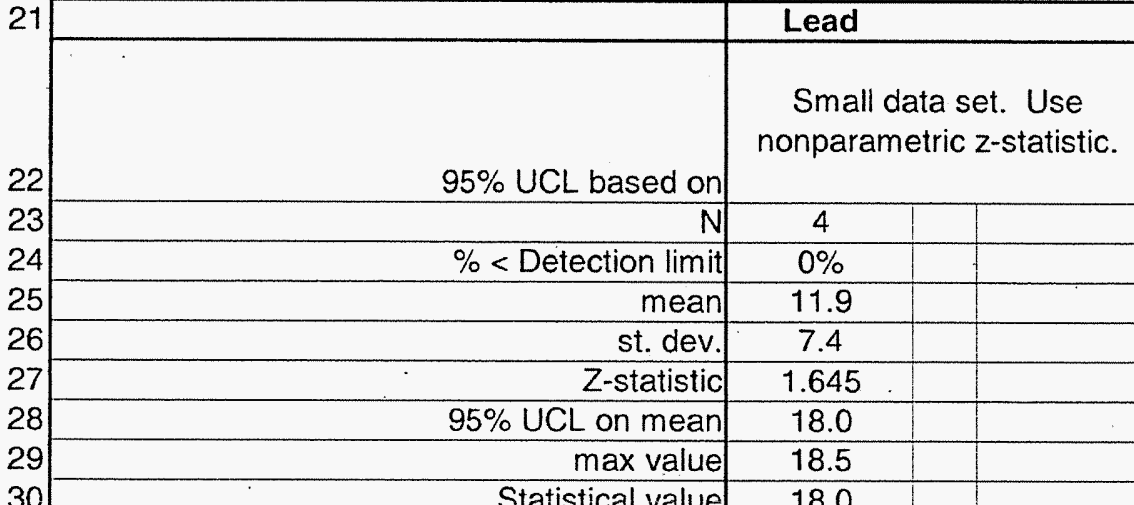

\begin{tabular}{l|l|l}
18.0 & \\
\hline
\end{tabular} (to. WAC 173-340 3-PART Test

$33 \quad 95 \%$ UCL $>$ Cleanup Limit? YES

\begin{tabular}{l|l|l|}
34 & $>10 \%$ above Cleanup Limit? & YES \\
\hline & YES \\
\hline
\end{tabular} 36 Any sample $>2 X$ Cleanup Limit? $\mathrm{NO}$ $37 \mathrm{GW}=$ groundwate

$39 \mathrm{NA}=$ not applicable 
Washington Closure Hanford

Originator M. J.Appel $m \cap A$

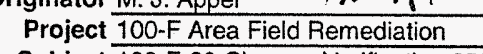

Subject $\frac{100-F-F-20 \text { Cleanup Verification } 95 \% \text { UCL Calculations }}{100}$

Split-Duplicate Analysis

Date $\frac{12 / 5 / 00}{14655}$

CALCULATION SHEET

\begin{tabular}{l} 
Calc. No. $\frac{0100 F-\text { CA.Vo274 }}{\text { Checked }}$ J.M.Capron Q \\
\hline
\end{tabular}

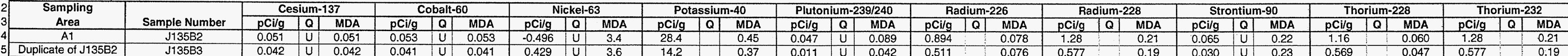

Rev. No. $\frac{0}{12 / 6 / 06}$

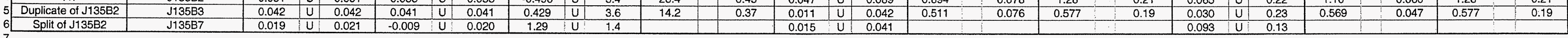
8 Sample Analysis:

\begin{tabular}{|c|c|c|c|c|c|c|c|c|c|c|c|}
\hline \multirow{4}{*}{ Duplicate Analysis } & DL & 0.1 & 0.05 & 30 & 0.5 & 1.0 & 0.1 & 0.2 & 1.0 & 1.0 & 1.0 \\
\hline & Both > MDA? & No-Stop (acceptable) & No-Stop (acceptable) & No-Stop (acceptable) & Yes (continue) & No-Stop (acceptable) & Yes (continue) & Yes (continue) & No-Stop (acceptable) & Yes (continue) & Yes (continue) \\
\hline & $\begin{array}{c}\text { Boin }>5 x \mid \mathrm{UL} \text { ? } \\
\text { RPD }\end{array}$ & & & & $66.7 \%$ & & $\frac{545 \%}{50}$ & No-Stop (acceptable) & & No-Stop (acceptable) & No-Stop (acceptable) \\
\hline & Difference > 2 TDL? & No - acceptable & No - acceptable & No - acceptable & Not applicable & No- acceptable & Not applicable & Yes - assess further & No- acceptable & No - acceptable & No- acceptable \\
\hline \multirow[t]{2}{*}{ Split Analysis } & $\begin{array}{l}\text { Both > MDA? } \\
\text { Both }>5 \times T \text { TDL? }\end{array}$ & No-Stop (acceptable) & No-Stop (acceptable) & No-Stop (acceptable) & No-Stop (acceptable) & No-Stop (acceptable) & No-Stop (acceptable) & No-Stop (acceptable) & No-Stop (acceptable) & No-Stop (acceptable) & No-Stop (acceptable) \\
\hline & \begin{tabular}{|l|l} 
Difference $>2 \mathrm{TDL}$ \\
\end{tabular} & No- acceptable & No- acceptable & No - acceptable & & No- acceptable & & & No - acceptable & & \\
\hline
\end{tabular}

\section{Split-Duplicate Analys}

19 Split-Duplicate Analysis
20 Shallow Zone Sample Results: Nonradionuclides 20 Shallow Zone $S$

\begin{tabular}{|c|c|c|c|}
\hline ow Zones & & & \\
\hline & r. & 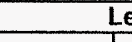 & \\
\hline Area & Sample Num! & $\mathrm{mg} / \mathrm{kg}$ & PQL \\
\hline A1 & J135B2 & 10.9 & 0.30 \\
\hline
\end{tabular}

\begin{tabular}{|c|c|c|c|c|}
24 & Duplicate of J135B2 & J135B3 & 11.9 & 0.30 \\
\hline & Split of J135B2 & J135B7 & 11.4 & 0.15 \\
\hline
\end{tabular}

27 Sample Analysis:

\begin{tabular}{|c|c|c|}
\hline \multicolumn{2}{|c|}{ TDL } & \\
\hline \multirow{2}{*}{ Duplicate Analysis } & \begin{tabular}{|l|} 
Both $>\mathrm{PQL}$ or MDA? \\
Both $>5 \times \mathrm{XPT}$ ?
\end{tabular} & $\frac{\text { Yes (continue) }}{\text { No-Ston (accontable) }}$ \\
\hline & & \\
\hline \multirow{3}{*}{ Split Analysis } & $\begin{array}{l}\text { Difference }>2 \text { i ILL? } \\
\text { Both }>\text { PQL? }\end{array}$ & $\begin{array}{l}\text { Noo acceptable } \\
\text { Yes (continue) }\end{array}$ \\
\hline & $\begin{array}{c}\text { Both > 5xTDL? } \\
\text { RPD }\end{array}$ & No-Stop (acceptable) \\
\hline & Difference $>2 \mathrm{TDL}$ ? & No-acceptable \\
\hline
\end{tabular}

37 Note: The signiticance of the reponed APD values, including values greater than $30 \%$, is addressed

$38 \mathrm{MDA}=$ minimum detectable activis
$39 \mathrm{PQL}=$ practical quantitation limit

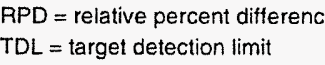

$40 \mathrm{QQL}=$ quallifier

$\mathrm{TDL}=$ target dete
$U=$ undetected 


\section{DISTRIBUTION}

U.S. Department of Energy

Richland Operations Office

D. C. Smith (5) A3-04

DOE-RL Public Reading Room H2-53

Fluor Hanford, Inc.

J.P. Shearer (WIDS) A0-21

Washington Closure Hanford

M. J. Appel H4-23

M. A. Buckmaster $\quad$ X9-07

S. W. Callison $\quad X 9-07$

R. A. Carlson $\quad \mathrm{X0}-17$

S. W. Clark H4-23

J. S. Decker $\quad \mathrm{X} 0-17$

L. A. Dietz H4-22

L. M. Dittmer H4-23

M. T. Hughes H4-23

J. E. Thomson H4-22

Records and Document Control H4-11

Hanford Technical Library $\quad$ P8-55 
CVP-2006-00009

Rev. 0

Distr-2 